\title{
Review
}

\section{Mechanisms underlying the cardiac pacemaker: the role of SK4 calcium-activated potassium channels}

\author{
David WEISBROD, Shiraz Haron KHUN, Hanna BUENO, Asher PERETZ, Bernard ATTALI*
}

Department of Physiology \& Pharmacology, Sackler Faculty of Medicine, Sagol School of Neuroscience, Tel Aviv University, Tel Aviv 69978, Israel

\begin{abstract}
The proper expression and function of the cardiac pacemaker is a critical feature of heart physiology. The sinoatrial node (SAN) in human right atrium generates an electrical stimulation approximately 70 times per minute, which propagates from a conductive network to the myocardium leading to chamber contractions during the systoles. Although the SAN and other nodal conductive structures were identified more than a century ago, the mechanisms involved in the generation of cardiac automaticity remain highly debated. In this short review, we survey the current data related to the development of the human cardiac conduction system and the various mechanisms that have been proposed to underlie the pacemaker activity. We also present the human embryonic stem cellderived cardiomyocyte system, which is used as a model for studying the pacemaker. Finally, we describe our latest characterization of the previously unrecognized role of the SK4 $\mathrm{Ca}^{2+}$-activated $\mathrm{K}^{+}$channel conductance in pacemaker cells. By exquisitely balancing the inward currents during the diastolic depolarization, the SK4 channels appear to play a crucial role in human cardiac automaticity.
\end{abstract}

Keywords: cardiac pacemaker; sinoatrial node; SK4 $\mathrm{K}^{+}$channel; $\mathrm{Ca}^{2+}$ clock model; voltage clock model

Acta Pharmacologica Sinica (2016) 37: 82-97; doi: 10.1038/aps.2015.135

\section{Introduction}

Normal cardiac function depends on the adequate timing of excitation and contraction in the various regions of the heart and on an appropriate pacemaker rate. This complex task is implemented by the highly specialized electrical properties of the various elements of the heart system, including the sinoatrial node (SAN), atria, atrioventricular node (AVN), HisPurkinje conducting system, and ventricles. Additionally, the different regions of the heart are endowed with various combinations of ion channels, pumps and exchangers yielding distinct action potential (AP) waveforms and durations.

Although all cardiomyocytes are initially endowed with pacemaker activity in the early embryonic stages, most cardiac cells eventually differentiate into the working myocardium, which lacks pacemaker properties. Only a small population of embryonic cardiomyocytes form SAN, AVN and the bundle of His ${ }^{[1]}$. In this short review, we survey the development of the human cardiac conduction system and the various mechanisms that have been proposed to underlie the pacemaker activity. We also present the human embryonic stem cellderived cardiomyocyte system, which is used as a model for

\footnotetext{
* To whom correspondence should be addressed.

E-mail battali@post.tau.ac.il

Received 2015-09-17 Accepted 2015-11-25
}

studying the pacemaker, and the most recent characterization of the previously unrecognized role of the SK4 $\mathrm{Ca}^{2+}$-activated $\mathrm{K}^{+}$channel conductance in pacemaker cells.

\section{Development of the human cardiac conduction system}

The human heart becomes the first functional organ at the beginning of the 3rd week of development. After 21 days of embryogenesis, a human embryo measures less than $5 \mathrm{~mm}$, and the primordial heart is a "cardiac tube" that is connected to the circulation system through the inflow and outflow tracts at the entrance and at the exit of the nascent organ, respectively (Figure 1A). The primitive cells, which derive from the cardiac mesoderm, have not yet developed sarcomeres and endoplasmic reticulum. However, the primitive cells exhibit the molecular signatures of "slow conduction", such as the expression of the T-box transcription factor Tbx3, the hyperpolarizationactivated cyclic nucleotide-gated channel $4(\mathrm{HCN} 4)^{[2,3]}$, the L- and T-type voltage-gated calcium channels, and connexin (Cx) 45. Connexin 30.2 is also specifically expressed in the primitive mouse heart ${ }^{[4]}$, but its human analog, $\mathrm{Cx} 31.9$, is not detectable ${ }^{[5]}$. Taken together, these characteristics confer an asthenic peristaltic myogenic oscillatory automaticity to the single chamber organ, which is observed as a sinusoidal signal in an ECG (Figure 1A) ${ }^{[6]}$. Importantly, all of the cells exhibit an intrinsic spontaneous pacemaker activity, but a specific 
A

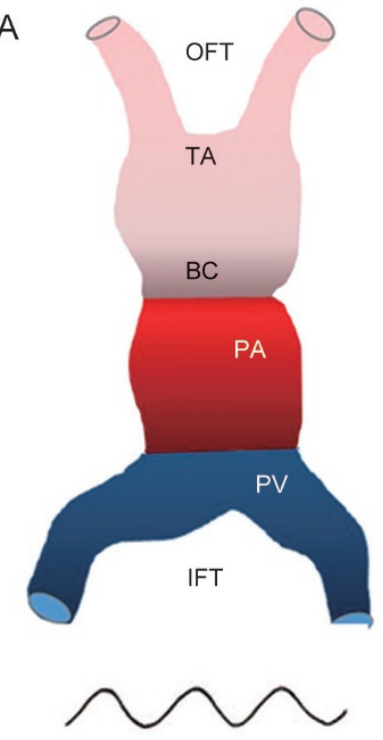

B

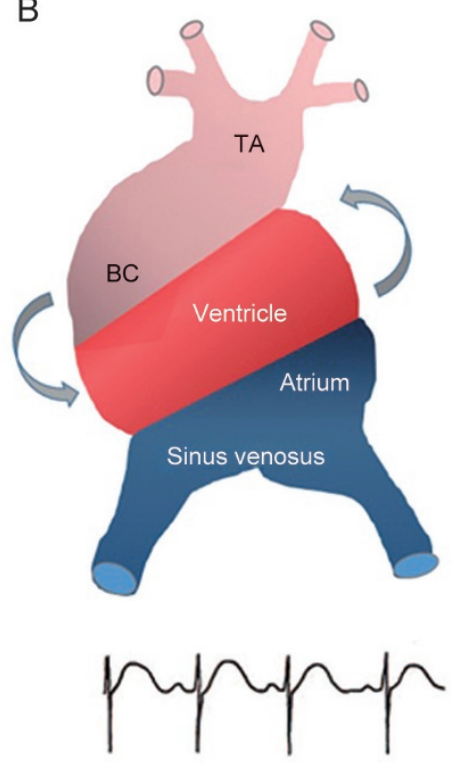

Figure 1. Schematic overview of heart development and the associated ECG. (A) At 21 days of embryogenesis, the cardiac tube is connected to the inflow (IFT) and outflow tracts (OFT) and generates a primitive activity and a sinusoidal ECG. TA, truncus arteriosus; BC, bulbus cordis; PA, primitive atrium; PV, primitive ventricle. (B) At 24 days of embryogenesis, there is expansion of the chambers and the appearance of an "adult-like ECG". The sinus venosus, atrium and ventricle appear.

subpopulation of cells that are localized in the posterior part of the tube contracts faster and imposes a higher rate, which leads to unidirectional circulation from the venous pole (influx tract) to the arterial pole (outflow tract) ${ }^{[7]}$.

The necessary structural and physiological adaptations of the primitive heart occur with the growth of the embryo and the sophistication of the circulation system. The proliferation of the atrial and ventricular balloons, which are located dorsally and ventrally to the cardiac tube axis, respectively, give rise to the following distinct areas: the sinus venosus, the atrium, the atrioventricular canal, the left ventricle, the right ventricle and the aortic sac (Figure 1B). Throughout the "looping process" during the formation of the chambers at the end of the first month of development, the heart folds and adopts an "S-shape" ${ }^{[8]}$. These structural modifications are accompanied by changes in the electrical properties of the organ, causing heterogeneity in the conduction system ${ }^{[9,10]}$. The sinus venosus and the atrioventricular canal exhibit the same low-velocity pattern as the primitive cells of the cardiac tube, whereas the newly synthetized cells (chamber areas) display the characteristics of a "high-velocity/high pressure" system. Histologically, this proliferative "pre-chamber myocardium" contains well-organized sarcomeres and developed endoplasmic reticulum. Molecularly, the extinction of Tbx3 leads to the appearance of "high conductance" proteins ${ }^{[11-13]}$, such as the connexins $\mathrm{Cx} 40$ and $\mathrm{Cx} 43^{[14]}$, and the replacement of the Land T-type $\mathrm{Ca}^{2+}$ channels by the fast voltage-activated sodium channel Scn5a (Nav1.5) ${ }^{[15]}$. HCN4 expression is also strongly decreased in the working myocardium, as this tissue loses its intrinsic pacemaker activity ${ }^{[16-18]}$. The ventricular conduction is provided by the trabecular myocardium from the dorsal part of atrioventricular canal, which expresses the fast-conducting connexins ${ }^{[19,20]}$. The specific characteristics of the AV canal are responsible for the "AV delay", an electrical coupling between the slow and fast-conducting segments. This establishment of a two-speed conducting system at the 25th day of development is a critical feature for the proper functioning of the heart ${ }^{[21]}$, as it guarantees that the ventricular segment will not contract before the contraction of the upstream portions of the heart ends. In the sinus venosus, $\mathrm{HCN} 4$ and Tbx 3 expression are progressively restricted to a specific area, the "sinus node primordium" or "primary sinoatrial node" ${ }^{\text {[22]; }}$, the other cells from this structure (right and left sinus horns) eventually lose their spontaneous activity and become working atrial myocytes during the "atrialization process". This primary sinoatrial node then grows and forms a "head" that extends into the right sinus horn ${ }^{[23]}$. Small networks of cells, the internodal tracts, connect the SAN to the remodeled AV area and send projections into the right and left atria (Bachmann's bundle ${ }^{[17,24]}$. Another SAN can be observed in the left part of the sinus horn, but this transient structure usually degenerates rapidly ${ }^{[25]}$. A large portion of the atrioventricular canal gradually disappears by differentiation into the working myocardium or apoptosis. Only a small continuum of the $\mathrm{Tbx}^{+} / \mathrm{C} \times 45^{+} / \mathrm{HCN} 4^{+}$primitive myocardium remains active in the conductive system. At approximatively the 5th week of embryogenesis, these cells give rise to the "atrioventricular node" (AVN), the right and left atrioventricular ring bundles. These ring bundles surround the forming atrioventricular valves ${ }^{[26]}$. The left bundle, which is already observed in the young embryonic heart, is localized close to the mitral valve. The right bundle, which develops in fetal and neonatal stages, forms around the tricus- 
pid valve. A fibrous structure then separates the atria from the ventricles, preventing any electrical coupling and potential arrhythmias, and the AV node remains as the only myocardial connection point between the atria and the ventricles. The AV bundle emerges at the crest of the forming interventricular septum. This structure displays increasing levels of high conduction proteins (CX40) while sustaining the levels of primitive marker Tbx3. As the AV canal shrinks, another fast conduction system is required to supply the growing ventricles ${ }^{[1]}$. The "peripheral ventricular conduction system" is the last element of the conduction system to differentiate. In contrast to the other conductive structures, it does not arise from the $\mathrm{Tbx}^{+}$myogenic precursors of the cardiac tube. Although the ventricles develop, two different synthetized myocardium subpopulations appear: a "compact working component" and a "trabecular component". The trabecular myocardium is the origin of the peripheral ventricular conduction system. These cells still display spontaneous pacemaker activity, express HCN4, and exhibit a "high-velocity Cx45/Scn5a phenotype". The left and right His branches emerge during the interventricular septation, when the trabecular myocytes penetrate inside the compact components of the septum ${ }^{[27]}$. With the thickening of the ventricle lateral and ventral walls, the trabecular myocytes develop an additional structure, the subendocardial Purkinje network ${ }^{[21,28]}$, which notably develops in response to an endothelial paracrine effect during the vascularization of the ventricles.

In the mature human heart and under physiological situations, the pacemaker activity is generated in the SAN, the dominant structure of the conduction system, which is localized in the top region of the right atrium close to the superior vena cava (Figure 2). The cyclic and slow spontaneous depolarization spreads through the internodal tract and Bachmann's bundle to reach the AV node at the base of the right atrium. This atrial contraction or "atrial systole", which is visible as a "P-wave" in the ECG, pushes the blood into the ventricles (Figure 2). The low-velocity characteristics of the AV node are crucial for a complete, active ventricular filling. The AV delay or "P-Q interval" is observable in the ECG as a segment of the isoelectric line following the P-wave. The electric impulse then reaches the His bundle and the fast-conducting components of the conduction system. Depolarization occurs rapidly, splitting into the two His branches of the interventricular septum and spreading through the Purkinje network inside the myocardium, leading to the "ventricular systole", known as the contraction of the ventricles from the apex to base, and ejection of the blood into the systemic or pulmonary circulation. This depolarization occurs from the endocardium through the epicardium and can be observed as the "QRS complex" in the ECG (Figure 2). Finally, the ventricles repolarize. This is the "ventricular diastole" or "T-wave" in the ECG, where the ventricles relax and then progressively start

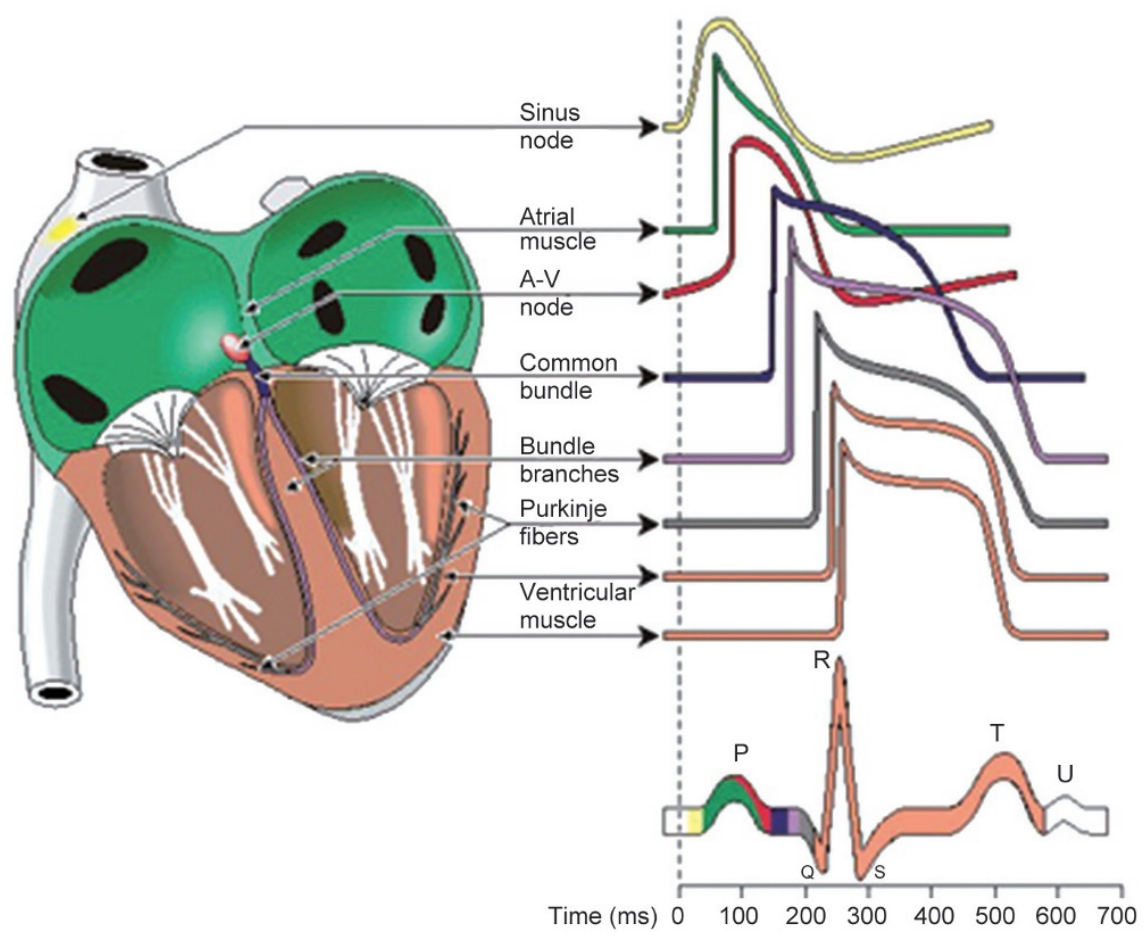

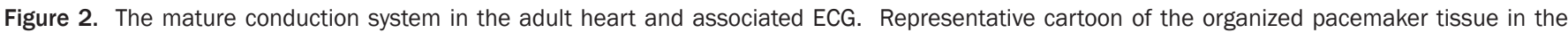

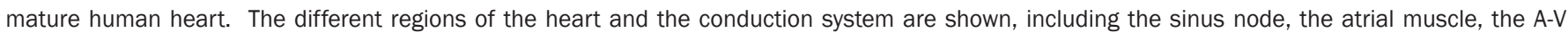

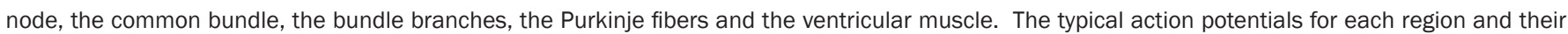

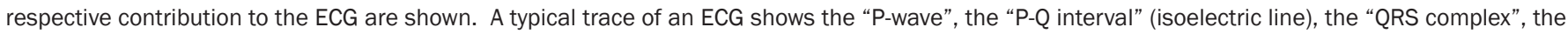
"T-wave" and the "U-wave". 
their passive filling process. The "U-wave" is thought to represent the repolarization of the papillary muscles or Purkinje fibers.

Although the AV node, AV bundle, His and Purkinje cells display spontaneous electric activities when isolated and recorded with the patch clamp technique, their intrinsic firing rate is lower than the SAN cells (30-40 depolarizations per minute in the His/Purkinje cells, 40-50 in the AVN or AV bundle, and approximately 60-75 in the SAN). This "SAN overdrive suppression" on the other elements of the conductive network explains its leading role in driving the pacemaker. Therefore, these structures are confined to a propagative function, even if they can act as a "pacemaker backup" in the case of SAN failure. However, due to their intrinsic electrical properties, they can also become potential arrhythmogenic sources under pathophysiological situations.

\section{Proposed mechanisms accounting for the cardiac pacemaker activity}

Jan Evangelista PURKINJE identified a ventricular network in 1839, Whilhem HIS JR observed a bundle within the interventricular septum in 1893, and Sunao TAWARA identified the AV node in 1906. The SAN was anatomically discovered by Arthur KEITH and Martin FLACK in 1907, although a pacemaker structure in the right atrium was proposed by Walter GASKELL much earlier in 1880. While the anatomical structures of the conduction system were identified more than 100 years ago, the molecular mechanisms underlying the cardiac automaticity remain controversial.

The pacemaker activity of a cell can be defined as its ability to spontaneously and cyclically generate an electric signal. To achieve this, the membrane potential of the SAN cell needs to slowly depolarize to a threshold, which is a specific voltage required for the generation of an AP. This depolarization, called "Diastolic Depolarization" (DD) or "pacemaker depolarization", results from a small net inward current flowing across the cell membrane and is the key feature of cardiac automaticity. DD occurs during diastole at the end of an action potential and is responsible for triggering the next action potential. Without diastolic depolarization, the heart would simply be unable to beat spontaneously. A crucial requirement for rhythmic automaticity is the existence of inward currents at diastolic potentials and a subtle dynamic integration of the sarcolemmal ion channels, transporters and $\mathrm{Ca}^{2+}$ cycling proteins ${ }^{[29]}$.

\section{Membrane or voltage clock model}

This model involves a combination of different ion channel activities during diastolic depolarization. One of the most important candidates is the "funny current" or " $I_{\mathrm{f}}$ " $\left(I_{\mathrm{h}}\right.$ in neurons) that was discovered in 1979 and found to be responsible for heart rate acceleration under noradrenaline stimulation ${ }^{[30,31]}$. Initially mistakenly described as a "potassic" current ${ }^{[32,33]}$, this "pacemaker current" was actually a non-specific inward cationic current produced by the hyperpolarization-activated and cyclic nucleotide-gated channels (HCN channels), which structurally resemble the $\mathrm{K}^{+}$channel superfamily ${ }^{[34]}$. Despite the presence of a potassium selectivity filter motif (GYG) and a global structure that resembles the potassium channels, $\mathrm{HCN}$ channels are also permeable to $\mathrm{Na}^{+}{ }^{[35]}$ and, to a much lesser extent, to $\mathrm{Ca}^{2+}$ ions ${ }^{[36]}$. At physiological voltages, the $\mathrm{Na}^{+}$influx via the $\mathrm{HCN}$ channels is larger than the $\mathrm{K}^{+}$outflow. Functionally, the $I_{\mathrm{f}}$ current is distinguished by its unique electrophysiological properties. Whereas all of the other existing voltage-gated cationic currents are activated by depolarization, the HCN channels open in response to membrane hyperpolarization. This difference explains the reason why the atypical current was also called the "funny current". Physiologically, at the end of an action potential, the membrane hyperpolarization activates the HCN channels, which slowly generate an inward depolarizing current until it reaches the threshold and subsequently generates a new action potential (Figure 3, left panel).

Four isoforms of the HCN channels are expressed in mammals, and their expression levels vary considerably depending on the animal model ${ }^{[34,37]}$. It is generally accepted that the HCN4 subtype is the most abundantly expressed isoform in the cardiac conductive tissue, with predominance in the human, rabbit and rodent $\mathrm{SAN}^{[38]}$. In addition to HCN4 and according to their transcript levels in SAN, HCN2 is expressed in mouse and HCN1 is expressed in rabbit ${ }^{[39]}$. HCN3 was recently observed in rodent ventricular myocytes ${ }^{[40]}$. As HCN3 has a lower range of activation in working cardiomyocytes, the $I_{\mathrm{f}}$ current density is very small in those type of cells, which may be why it is considered as a "background current", which is in contrast to its role in SAN ${ }^{[41]}$. The funny current is regulated by cAMP, which directly binds to a "cyclic nucleotide-binding domain" at the C-terminus of the channel. In response to sympathetic activity, adenylate cyclase increases intracellular cAMP levels, which leads to a "rightward-shift" of the $I_{\mathrm{f}}$ activation curve, and, subsequently, a larger current at the same voltage. This modulation explains the stronger diastolic depolarization slope (DD slope) and the increase in pacing rhythm in response to adrenaline. By contrast, acetylcholine decreases the cAMP levels in the SAN, leading to a smaller current at the same voltage (left-shift of the activation curve), a weaker DD slope and bradycardia ${ }^{[42]}$. The $\beta$ accessory subunit MiRP1 changes the activation kinetics of the current in opposite ways depending on the HCN isoform. Although it has been reported to increase the activation kinetics and the currents of HCN1 and $2^{[43,44]}$, it decreases the activation kinetics but increases the $I_{\mathrm{f}}$ current when it is associated with $\mathrm{HCN}^{[45]}$. Other $\mathrm{HCN}$ regulatory mechanism have been described, including phosphatidylinositol 4,5-bisphosphate $\left(\mathrm{PIP}_{2}\right)$ modulation $^{[46]}$ or the direct actions of kinases ${ }^{[47]}$ and phosphatases ${ }^{[48,49]}$. Loss of function of HCN4 due to mutations or nonspecific pharmacological blockade leads to sick sinus syndrome, which is a general inability of the SAN to impose its sinusal rhythm on the conducting system. In most cases, this disease is the manifestation of an idiopathic degeneration of the SAN leading to arrhythmia, such as sinus bradycardia, alternating periods of tachycardia and bradycardia ${ }^{[50]}$ (tachy- 


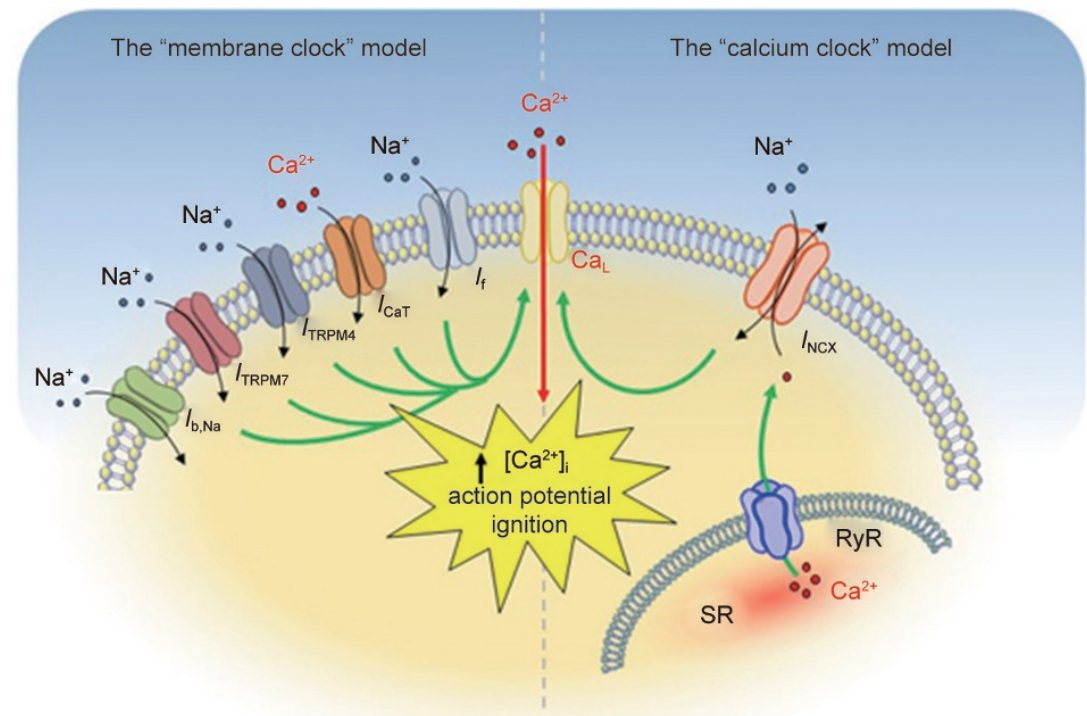

Figure 3. The "membrane clock" model. This model is a general, integrative model that includes the different channels or channel-receptors that are involved in this process. The $I_{\mathrm{f}}$, the sustained $I_{\mathrm{b}, \mathrm{Na}}, I_{\mathrm{CaT}}$ (Cav3.1 and Cav3.2), $I_{\text {TRPM } 4}$ and $I_{\text {TRPM7 }}$ inward currents are all good candidates that may be responsible for the diastolic depolarization, alone or in combination. The "calcium clock" model (adapted from EG Lakatta, Ref [85]). Diastolic spontaneous calcium release increases the cytoplasmic calcium concentrations and activates NCX-1 in the forward mode. The inward $I_{\text {NCX }}$ current depolarizes the membrane until the threshold is achieved.

brady episodes) or, in the worst cases, to sinus arrest. Animal models of total or partial HCN knockout yielded varying results. A specific and unconditional atrial suppression of $\mathrm{HCN} 4$ in the knockout mice leads to in utero death without histological abnormalities, whereas electrophysiological studies of the isolated cells from these mouse embryos showed a reduced level of spontaneous pacemaker activity, despite the $75 \%-90 \%$ decrease in the $I_{\mathrm{f}}$ current density ${ }^{[51]}$. The same study observed that cAMP regulation was impaired in the cardiomyocytes from $\mathrm{HCN}^{-} /^{-}$mice, whereas another study presented opposite results with a HCN4 conditional knockout in adult mice ${ }^{[52]}$. Taken together, these results indicate that the funny current is not the only component of the pacemaker diastolic slope (Figure 3, left panel).

In 1990, Denyer and Brown performed electrophysiological studies on rabbit SAN cells. Although they used cesium at a concentration of, which nearly completely blocked the $I_{\mathrm{f}}$, the spontaneous firing rate of the cells was reduced but not inhibited. After confirming that the cesium blockade of the $I_{\mathrm{f}}$ did not induce changes in the other inward or outward currents, they conclude that a sustained, previously unidentified current is present in the SAN cells ${ }^{[53]}$. The conductance was better characterized in a subsequent study as a poorly selective inward cationic current ${ }^{[54]}$ even though it exhibits a stronger permeability to sodium ${ }^{[55]}$. Interestingly, this $I_{\mathrm{b}, \mathrm{Na}}$ (sodium background) current is insensitive to high concentrations of TTX but can be modulated by the calcium channel blocker nicardipine $^{[56]}$ or the agonist Bay K644. Surprisingly, this sustained current is also regulated by beta agonists or by the parasympathetic system, similar to $I_{\mathrm{f}}$. Although the mechanism has not yet been described, isoproterenol increases the current whereas acetylcholine produces the opposite effect ${ }^{[57]}$. $I_{\mathrm{b}, \mathrm{Na}}$ has been reported in rabbit, rat and guinea pig SAN cells ${ }^{[58]}$. With an activation threshold at approximately $-60 /-70 \mathrm{mV}$ and a maximum current of $-50 \mathrm{mV}$, this channel can easily contribute to the DD slope in synergy with $I_{\mathrm{f}}$ (Figure 3, left panel).

Two different subfamilies of voltage-gated calcium channels are expressed in the heart pacemaker tissue ${ }^{[59-61]}$, the highthreshold "L-type" $\left(\mathrm{Ca}_{\mathrm{v}} 1.2, \mathrm{Ca}_{\mathrm{v}} 1.3\right)$ and the low-threshold "T-type" channels $\left(\mathrm{Ca}_{\mathrm{v}}\right.$ 3.1, $\left.\mathrm{Ca}_{\mathrm{v}} 3.2\right)$, which are distinguished by their different electrophysiological and pharmacological properties. The high-threshold L-type channels begin to be activated at $-30 \mathrm{mV}$, whereas the T-type channels are activated at more hyperpolarizing voltages (approximately $-60 \mathrm{mV}$ ). The T-type isoforms $\mathrm{Ca}_{\mathrm{v}} 3.1$ and $\mathrm{Ca}_{\mathrm{v}} 3.2$ appear at an early stage of cardiogenesis and are mainly localized in the AV canal. In the healthy adult mammalian heart, they are not expressed in the working cardiomyocytes but have been identified in the SAN, AVN and Purkinje fibers ${ }^{[62]}$. In the SAN, the levels of the $\mathrm{Ca}_{\mathrm{v}} 3.1$ transcript are higher than $\mathrm{Ca}_{\mathrm{v}} 3.2^{[63]}$. This restriction of the T-type channels to the conductive system tends to indicate a hypothetical specific involvement in the pacemaker activity. In fact, $\mathrm{Ca}_{\mathrm{v}} 3.1$ knockout mice display arrhythmias, such as bradycardia, and an AVN delay in ECG. Spontaneous action potentials recorded from isolated SAN or AVN cells from the $\mathrm{Ca}_{\mathrm{v}} 3.1$ knockout mice have a shallower DD slope and a lower instantaneous firing rate than wild-type cells ${ }^{[64]}$. Given that wild-type cells are activated by hyperpolarizing membrane voltages, the inward currents of these channels can contribute to the pacemaker slope (Figure 3, left panel).

L-type $\mathrm{Ca}^{2+}$ channels have been described as having a crucial role in the excitation-contraction coupling $(\mathrm{E}-\mathrm{C})$ as they 
are expressed at high levels in skeletal muscle and the working myocardium. In fact, their sustained activity in phase 2 of an AP (plateau) is necessary for a proper interaction between the sarcomeric molecules and a contraction of the myocytes. $\mathrm{Ca}_{\mathrm{v}} 1.2$ and $\mathrm{Ca}_{\mathrm{v}} 1.3$ are expressed in the SAN pacemaker cells ${ }^{[61]}$, but unlike their role in the working myocytes, these currents are essential for generating the action potential upstroke of the "low-velocity" pacemaker cells. $\mathrm{Ca}_{\mathrm{v}} 1.2$ is a ubiquitous current that is expressed equally in all human heart regions, whereas $\mathrm{Ca}_{\mathrm{v}} 1.3$ was expressed more specifically in the SAN and the human $\mathrm{AVN}^{[65]}$. Pharmacologically, there are currently no reagents available to discriminate between the two distinct currents, but they can be distinguished based on their voltagedependent activation. $\mathrm{Ca}_{\mathrm{v}} 1.2$ channels exhibit slower activation kinetics, which occurs at more depolarizing membrane potentials than for $\mathrm{Ca}_{\mathrm{v}} 1.3^{[66,67]}$. ECG performed on $\mathrm{Ca}_{\mathrm{v}} 1.3^{-} /^{-}$ null mutant mice revealed bradycardia, SAN dysfunction and an $\mathrm{AV}$ block ${ }^{[68]}$. APs that were spontaneously recorded from isolated SAN or AVN cells also showed a decrease in the pacing rate and the DD slope, pointing to the important role of these channels in the pacemaker function ${ }^{[65,67]}$.

Recently, different transient receptor potential (TRPM) channels have also been described as having a role in this physiological process. TRPM4, a non-selective, calcium-activated cation channel was characterized in the rodent SAN ${ }^{[69]}$. This sodium and potassium inward current is positively regulated by $\left[\mathrm{Ca}^{2+}\right]_{i}$ and negatively regulated by ATP. These channels have also been reported in the SAN from other species ${ }^{[70,71]}$. Pharmacological inhibition or full suppression in knockout mice leads to a decrease in the AP rate (Figure 3, left panel). Some other channels have also been suggested to be involved in the pacemaker activity but more as regulatory elements than main components of the DD slope. This is the case for TRPM7, a divalent cation-permeant channel kinase that is expressed in various tissues, including the heart. Although conditional deletion in late-stage developing embryos does not disturb cardiac development, intermediate-stage or earlystage knockout leads to a decrease in HCN4 expression in the primitive heart, congestive heart failure or in utero death, respectively ${ }^{[72]}$. Restricted TRPM7 deletion in the mouse SAN disrupts cardiac automaticity in vivo, leading to sinus pauses and an AV block. Molecularly, TRPM7 knockdown alters HCN4 expression, leading to its downregulation and subsequent changes in automaticity ${ }^{[73]}$.

Inward-rectifier potassium currents, such as $I_{\mathrm{KACh}}$ or $I_{\mathrm{KATP}}$, which are expressed in the SAN, can also modulate the DD slope. The $I_{\mathrm{KACh}}$ channels open in response to acetylcholine binding to the muscarinic receptor in the SA. The consecutive hyperpolarizations that are generated lead to a reduction in the pacing rate ${ }^{[7]}$. Interestingly, cholinergic modulation also affects $I_{\mathrm{f}}$, but with a different affinity. High levels of acetylcholine are required to activate $I_{\mathrm{KACh}}$ whereas nanomolar concentrations are sufficient to regulate the funny current ${ }^{[75]}$. $I_{\text {KATP }}$ is activated in response to a reduction of the cytoplasmic ATP levels ${ }^{[76,77]}$; similar to $I_{\mathrm{KACh}}$ its outward current hyperpolarizes the membrane and decreases the pacing rate.

\section{Calcium clock model}

In 1972, Fabiato and colleagues ${ }^{[78]}$ observed that cardiomyocytes from which the membrane has been removed still exhibited spontaneous contractions. Calcium is known to play a central role in the E-C coupling in "working" cardiomyocytes. In fact, during this physiological process, the depolarization of the sarcolemma generates an inward calcium current through the activation of the L-type $\mathrm{Ca}^{2+}$ channels, which is responsible for triggering a "calcium-induced calcium release" (CICR), a synchronous calcic wave, from the ryanodine (RyR) and $\mathrm{IP}_{3}$ receptors of the sarcoplasmic reticulum (SR). The subsequent $\left[\mathrm{Ca}^{2+}\right]_{i}$ increase is a key feature of a proper actin-myosin interaction and cardiomyocyte contraction ${ }^{[79-81]}$. In addition to the calcic wave, which results from a synchronous release through the SR receptors, spontaneous local calcium sparks have been observed in working myocardium ${ }^{[82,83]}$ and Purkinje fiber cells ${ }^{[84]}$. These spontaneous $\mathrm{Ca}^{2+}$ oscillations occur locally in a submembrane region of the cell and propagate rapidly. These phenomena were initially thought to be only associated with cardiac arrhythmias ${ }^{[85]}$ until they were also reported in atrial pacemaker cells ${ }^{[86]}$. In fact, with the help of imaging techniques, $\mathrm{Ca}^{2+}$ chelating fluorophores and electrophysiology, $\mathrm{Ca}^{2+}$ transients were visualized during the DD slope and preceded the large entry of calcium through the calcium channels ${ }^{[87]}$. Alternative pharmacological approaches with SR blockers revealed modifications in the rate and the shape of the AP from guinea pig sinoatrial cells ${ }^{[88]}$. Evidence for a functional interaction between the ryanodine receptor-mediated $\mathrm{Ca}^{2+}$ release and the cardiac isoform of the NCX-1 $\mathrm{Na}^{+}-\mathrm{Ca}^{2+}$ exchanger ${ }^{[89-91]}$ gave rise to an alternative theory, "the calcium clock", in which diastolic spontaneous $\mathrm{Ca}^{2+}$ release activates the $\mathrm{Na}^{+}-\mathrm{Ca}^{2+} \mathrm{NCX}-1$ exchanger in its forward mode. In these conditions, the net electrogenic inward current resulting from the entrance of $3 \mathrm{Na}^{+}$and the extrusion of $1 \mathrm{Ca}^{2+}$ depolarizes the membrane of the cell toward the threshold and generates an action potential ${ }^{[92,93]}$ (Figure 3, right panel).

RyR2 and NCX-1 can be modulated by adrenergic stimulation. Indirect evidence showed that SAN cells displayed stronger and longer calcium sparks in response to isoproterenol and higher $I_{\mathrm{NCX}}$ currents ${ }^{[89,94,95]}$. Molecularly, the regulation mechanism occurs through direct cAMP/PKA-mediated regulation of RyR $2^{[94,96]}$ and eventually $I_{N C X}$, although this latter assumption is still being debated ${ }^{[97]}$. Conversely, as a homeostatic feedback mechanism, the regulation by $\mathrm{Ca}^{2+}$ calmodulin kinase II (CAMKII) decreases the $\mathrm{Ca}^{2+}$ sparks to stabilize them ${ }^{[98]}$. Mutations in RyR2 can lead to a cytoplasmic calcium leak and severe arrhythmias, such as the catecholaminergic polymorphic ventricular tachycardia CPVT1. Hyperphosphorylation of this receptor is also associated with heart failure ${ }^{[99]}$. An inducible general RyR2 knockout in mouse heart produces a reduced heart rate and severe arrhythmias in the $\mathrm{ECG}^{[100]}$. Similar to HCN, animal models with a total or targeted NCX-1 knockout gave inconsistent results. A total suppression of NCX-1 leads to embryonic lethality due to the absence of the spontaneous beating activity of the heart, despite the normal structural development and the existence 
of $I_{\mathrm{f}}$ currents. Paradoxically, despite the complete sarcomeric disorganization and the absence of spontaneous contraction, the NCX-1 $1^{-}$knockout in the ventricular and the SAN cells still has intact calcium transients, but they are uncoupled from the sarcolemma ${ }^{[101,102]}$. An inducible KO in the SAN from adult rodents is associated with a progressive diminution of the heartbeat, a disturbed pacemaker activity and a decrease in the amplitude of the spontaneous $\mathrm{Ca}^{2+}$ sparks ${ }^{[103]}$. However, other studies reached different conclusions. Another study with a knockout in SAN cells indicated that the cells still displayed a normal basal rhythm but did not respond to sympathetic or parasympathetic regulation ${ }^{[104]}$. Finally, pharmacological approaches using high concentrations of ryanodine on the entire SAN from wild-type rabbit only moderately decreased its pacing rate ${ }^{[105]}$.

Taken together, the membrane clock and calcium clock models are still highly debated ${ }^{[106]}$ and raise many counterpoints and paradoxes. New theories that integrate both models are emerging $^{[107-109]}$, but it remains challenging to provide a clear answer to the simple question that was asked more than a century ago.

\section{Human embryonic stem cell-derived cardiomyocytes: a model for studying the cardiac pacemaker}

For evident bioethical reasons, most studies that investigate the mechanisms underlying the cardiac pacemaker are performed on SAN cells from animals, mostly mice and rabbits. However, these species display significant differences in the values and fluctuations of their basal heart rates compared to humans (450-750 beat/min in mouse, 180-350 beat/min in rabbit, and $60-100$ beat/min in human). These variations result from notable interspecies differences in the dynamics and contributions of the calcium handling proteins, in the density of each current, and their regulation. Very few studies, however, have reported data from single cells that were dissociated from an excised human SAN ${ }^{[42,110]}$. Each of the studies was performed with isolated cells from a single SAN, but it was possible to compare a few electrophysiological parameters with rabbit cells. The action potentials recorded from human SAN cells are longer (higher action potential duration) with a weaker pacemaker slope, upstroke and firing rate than rabbit cells. The strong variations in the AP profile, and likely in the involvement of each molecular player, underline the fact that animals are a model and one should consider this point before extrapolating the results or a general pacemaker theory from one species to another.

It would be intuitive to use human cells to investigate the process involved in humans. In 1998, Thomson and Itskovitz derived cell lines from human blastocysts ${ }^{[111]}$. Similar to the studies of mice, the inner cell mass of human embryos was propagated and expanded, giving rise to different human embryonic stem cell (hES) lines. These pluripotent cells have the intrinsic ability for self-renewal and differentiation into the three embryonic germ layers (ectoderm, endoderm, and mesoderm). Following suspension culture, the hES colonies adopt spherical morphologies, or "embryoid bodies" (EBs), which mimic the embryonic shape, and they initiate a regional differentiation process into all type of cells, including spontaneous beating clusters ${ }^{[112]}$. Isolated cells from these clusters generate action potentials with diverse shapes, calcium transients and functional sarcomeres ${ }^{[113,114]}$. Cardiomyocytes derived from human embryonic stem cells (hESC-CMs) are considered to be a very promising therapeutic tool in cardiovascular research, as they have considerable potential for cell transplantation and tissue regeneration ${ }^{[115-117]}$. In the last decade, many studies have been published to better characterize these cells ${ }^{[118,119]}$, to improve the production protocols ${ }^{[120-122]}$ or to obtain specific, pure subpopulations ${ }^{[123-125]}$. In addition, because these cells beat spontaneously, analogous to the cardiac cells of the primitive heart, it is assumed that they can be used as a relevant model to investigate the molecular mechanisms underlying the human cardiac pacemaker activity.

\section{The calcium-activated potassium channel family}

The calcium-activated channels exhibit the characteristics of a transducer between the ubiquitous cytoplasmic calcium signals and the electrical variations of the cell membrane. Among the diverse types of channels that exhibit these properties, the calcium-activated potassium channel family (KCa) is heterogeneous. According to their unitary conductance, they have been classified into three subfamilies: BK, IK and SK, which are "big", "intermediate" and "small" conductance, respectively ${ }^{[126]}$.

The BK channels $\left(\mathrm{K}_{\mathrm{Ca}} 1.1\right)$, or "large conductance $\mathrm{Ca}^{2+}$ activated potassium channels", were first identified in 1979 by Heyer and Lux in the pacemaker neurons of the snail ${ }^{[127]}$ and cloned 15 years later ${ }^{[128]}$. This subfamily of channels differs from the IK and SK channels in their structure and biophysical properties. In addition to the well-known six transmembrane domains present in each subunit of voltage-gated potassium channels, a S0 membrane segment in the N-terminus and a cytoplasmic hydrophobic C-terminus containing a "calcium bowl" extend the a-subunit. Different $\beta$-subunits have been reported to be associated with the main structure of the protein $^{[129-131]}$. BK channels exhibit a large unitary conductance $(\approx$ $250 \mathrm{pS}$ ) and are modulated by increased cytoplasmic calcium concentrations and membrane depolarization ${ }^{[126]}$; they are abundant in the central nervous system ${ }^{[132]}$, smooth muscle cells $^{[133]}$, and leucocytes and have been recently identified in the mouse sinoatrial node ${ }^{[134,135]}$. The protective roles of BK channels, such as spike frequency adaptation, explain their increased expression in excitable cells. Pharmacologically, they are sensitive to charybdotoxin, paxilline and iberiotoxin.

The small conductance calcium-activated potassium channels SK1 ( $\left.\mathrm{K}_{\mathrm{Ca}} 2.1\right)$, SK2 $\left(\mathrm{K}_{\mathrm{Ca}} 2.2\right)$ and SK3 (K $\left.\mathrm{K}_{\mathrm{Ca}} 2.3\right)$ are encoded by three different genes, KCNN1, KCNN2 and KCNN3, respectively. These three channels, which were first cloned from rat and human brain by Köhler et al in 1996, exhibit a high sequence homology $(60 \%)^{[136]}$. Structurally, they are very similar to the voltage-gated potassium channel superfamily. The a-subunits form a tetramer, each comprising six transmembrane segments (S1 to S6) and cytoplasmic amino and car- 
boxyl termini. The S5-P-loop-S6 segments constitute the pore and the potassium selectivity filter, whereas the S4 transmembrane domain contains fewer gating charges than the voltagegated $\mathrm{K}^{+}$channels with only two positively charged residues compared with the 4-5 charges in classical voltage-gated channels ${ }^{[136]}$. These channels do not have an EF-hand domain motif and their activity is only calcium-dependent. The submicromolar intracellular calcium modulation is explained by the presence of a calmodulin binding site (CMBD) at the $\mathrm{C}$ terminus $^{[137,138]}$, which, upon calmodulin interaction, leads to conformational changes and channel opening. All of the SK channels exhibit similar steady-state activation curves for $\mathrm{Ca}^{2+}$ (half activation approximately $300-700 \mathrm{nmol} / \mathrm{L})^{[136,137,139]}$, which is a relatively low affinity. Electrically, SK channels contrast with Ohmic currents and display a strong inward rectification at positive voltages. The mechanism is still not clear but might be explained by an intracellular $\mathrm{Mg}^{2+}$ or $\mathrm{Ca}^{2+}$ voltage-dependent block ${ }^{[140]}$. The three subtypes differ in their tissue expression patterns and their pharmacological sensitivities to the bee venom toxin apamin. In the central nervous system, SK1 and SK2 are primarily expressed in the neocortex and hippocampal regions whereas SK3 is localized in more primitive areas, such as the basal ganglia or the thalamus ${ }^{[141]}$. They mediate the afterhyperpolarization, which ends the action potential ${ }^{[142]}$. In the periphery, the SK channels are expressed in T-lymphocytes and atrial cells and play an important role in atrial repolarization $^{[143-148]}$. SK1 channels are resistant to apamin ${ }^{[136]}$, and their unitary conductance varies from 11 to $26 \mathrm{pS}$ depending on the experimental conditions ${ }^{[149-151]}$. They can associate with SK2 to form heterotetrameric channels. SK2 channels are highly sensitive to apamin, and their unitary conductance has been reported to vary from 10 to $20 \mathrm{pS}{ }^{[136,139,140]}$. SK3 channels have a moderate affinity to apamin.

The SK4 intermediate calcium-activated channel $\left(\mathrm{K}_{\mathrm{Ca}} 3.1\right)$ is encoded by the gene KCNN4, which is localized in the q13.2 region of human chromosome $19^{[152]}$. Historically, this channel was discovered by Gardos in 1958, when he noted a correlation between the potassium outflow from erythrocytes and the intracellular EDTA/calcium competition ${ }^{[153]}$. Four decades later, it was cloned and biophysically characterized ${ }^{[154,155]}$. Although the main channel is a 428 amino acid protein, different mRNA transcripts have been reported (2.6 and $3.2 \mathrm{~kb}$ ), suggesting that there are different splice variants. Structurally, SK4 is also very similar to the canonical voltage-gated potassium channel superfamily, although it exhibits low homology $(40 \%)$ with the other SK subfamily members (Figure 4). Similar to the small calcium-activated channels, SK4 is only modulated by calcium through a calmodulin binding site in its $\mathrm{C}$ terminal region ${ }^{[156,157]}$ (Figure 4 ). In addition to the $\mathrm{Ca}^{2+}-\mathrm{CaM}$ conformational changes, which are necessary for channel opening, calmodulin itself regulates the assembly and trafficking of the protein to the cell membrane ${ }^{[158]}$. $\mathrm{K}_{\mathrm{Ca}} 3.1$ also has potential PKA and PKC phosphorylation sites. PKA and cAMP activate the channel ${ }^{[159]}$, in addition to an independent C-terminal ATPdependent phosphorylation ${ }^{[160,161]}$. SK4 is strongly expressed in erythrocytes, placenta, lung, prostate, bladder, thymus, and smooth muscle cells. However, it is almost completely absent in the brain ${ }^{[154,155]}$, although a recent report has demonstrated that SK 4 channels are expressed in the nodes of Ranvier of cerebellar Purkinje neurons ${ }^{[162]}$. Interestingly, until recently, SK4 channels were not detected in the heart ${ }^{[154,155]}$. Electrically, its single conductance varies from 10 to $42 \mathrm{pS}^{[163]}$ and also exhibits the same inward rectification as the other SK channels. However, SK4 differs in its higher affinity to intracellular $\mathrm{Ca}^{2+}$ (half activation at $95 \mathrm{nmol} / \mathrm{L}$ free $\mathrm{Ca}^{2+}$ ), which confers a functional role to the channel at physiological, basal intracellular $\left[\mathrm{Ca}^{2+}\right]_{i}$ concentrations (approximately $100 \mathrm{nmol} / \mathrm{L}$ ). Pharmacologically, SK4 channels are insensitive to apamin but are blocked by the scorpion toxin charybdotoxin and by different drugs, such as clotrimazole and, more recently, TRAM-34 ${ }^{[164]}$.

\section{The "membrane clock" and "calcium clock" in human embryonic stem cell-derived cardiomyocytes (hESC-CMs)} In stem cell research, a growing number of studies have been published the last decade focusing on cardiac regeneration $^{[117,165]}$ and on the pacemaker mechanism ${ }^{[166-172]}$. As hESCCMs usually start to beat spontaneously between the 9th and 12th day after differentiation begins, we focused our work on young cells (d11 to 21), which parallels the early beating cells of the cardiac tube ${ }^{[173]}$. By alternating the current and voltage clamp configurations of the patch clamp technique with a pharmacological approach on the same cell, we found that $32 \%$ of the hESC-CM population exhibited a prominent $I_{\mathrm{f}}$ pacemaker mechanism. In this subset of cells, the $I_{\mathrm{f}}$ blockers ZD7288 or zatebradine strongly decreased the funny current ${ }^{[174]}$, as monitored under voltage clamp, and led to a bradycardia and a depolarization of the maximum diastolic potential (MDP), which is frequently associated with a cessation of the pacemaker activity ${ }^{[173]}$. Similar concentrations of zatebradine were previously reported in hESC-CMs ${ }^{[175]}$ or rabbit SAN, and, interestingly, a suppression of the MDP notch could already be observed in those studies but without a clear explanation $^{[176]}$. The automaticity of those cells was not affected by KB-R7943 or the peptide FRCRCFa, two structurally different inhibitors of the NCX exchanger ${ }^{[177,178]}$. In the second subset of cells, although an $I_{\mathrm{f}}$ current could be easily recorded, its full blockade did not affect the spontaneous firing rate as monitored under voltage clamp. By contrast, the hexapeptide FRCRCFa or KB-R7943 strongly decreased the beating rate and depressed the pacemaker activity, resulting in the inhibition of the AP. Interestingly, the depolarizing effect of KB-R7943 on the cell automaticity was previously reported in cardiomyocytes isolated from 8.5 days rodent embryos ${ }^{[167]}$ and in guinea pig SAN cells ${ }^{[179]}$ but the mechanism was not explained. This " $I_{\mathrm{f}}$-independent" pacemaker mechanism was observed in a subset of cells that represented $41 \%$ of the hESC-CMs ${ }^{[173]}$. In the two cell subpopulations, the "membrane clock" and "calcium clock" were operating in a mutually exclusive manner, although the two conductances coexisted in the same cell and the $I_{\mathrm{NCX}}$ current density was higher than that of $I_{\mathrm{f}}$ at MDP ${ }^{[173]}$. The ubiquitous presence of $I_{\mathrm{f}}$ in all the tested hESC-CMs is also observed in early cardiogenesis ${ }^{[2,3]}$ and confirms the primi- 
tive embryonic phenotype of these cells. The selection of a privileged pacemaker mechanism does not correlate with the relative current densities of $I_{\mathrm{f}}$ and $I_{\mathrm{NCX}}$ and remains completely unknown ${ }^{[173]}$. In the remaining $26 \%$ of the hESC-CMs tested, both $I_{\mathrm{f}}$ and $I_{\mathrm{NCX}}$ blockers decreased the firing rate by less than $50 \%$. A cumulative negative chronotropic effect on the rate was observed when the cell was subsequently exposed to both types of antagonists ${ }^{[173]}$. These cells exhibited a "coupled" pacemaker mechanism in which the two inward currents were involved in the diastolic slope. Similar results were described in canine SAN cells ${ }^{[104]}$.

\section{Identification of SK4 channels in hESC-CMs, a previously unrecognized player in the cardiac pacemaker function}

Various studies have reported the expression and function of BK and SK channels in heart cells from various animal species. Although BK channels have been thought to be absent from the sarcolemma, a recent study showed a reduction of the heart rate when rat hearts were perfused with paxilline or iberiotoxin ${ }^{[134]}$. A subsequent study from the same group reported a lengthening of the diastolic depolarization in BK knockout $\left(\mathrm{KCnma1}^{-/-}\right)$mice ${ }^{[135]}$. The decreased heart rate was associated with slowed cardiac pacing due to the elongation of the sinus interval. The action potentials recorded from isolated SAN cells were reduced in BK knockout mice compared with WT animals. The heart rate was also slower in the SAN from the control mice treated with paxilline and iberiotoxin ${ }^{[135]}$. In addition, BK channel immunoreactivity and paxilline-sensitive currents were identified in the SAN from WT mice ${ }^{[135]}$. We used the same inhibitors to investigate the effect of BK blockade on the pacemaker but did not observe any effects on hESC-CMs ${ }^{[173]}$.

Recently, the three different isoforms of small conductance $\mathrm{Ca}^{2+}$-activated $\mathrm{K}^{+}$channels, SK1, SK2 and SK3, were identified in adult mouse and human hearts ${ }^{[144,145,151]}$. SK2 channels have been reported to operate in the late repolarization phase of the AP of human and rodent atrial cells. The knockout of the SK2 channels leads to a decrease in the firing rate of the AVN cells, whereas the overexpression of the channel is accompanied by shorter APs with increased frequency ${ }^{[147]}$. SK2 channels are also thought to maintain atrial fibrillation ${ }^{[148]}$. Apamin, a selective SK2 blocker, delays AP repolarization by elongating the $\mathrm{APD}_{50}$ in isolated mouse AVN and atrial cells at concentrations from 50 to $500 \mathrm{pmol} / \mathrm{L}^{[146,147]}$. We did not observe any effect on the rate, the MDP, or the $\mathrm{APD}_{50}$ of the young hESC$\mathrm{CMs}$, even after prolonged exposures to concentrations up to $1 \mu \mathrm{mol} / \mathrm{L}$, excluding any involvement of this conductance in the pacemaker mechanism at the young stage of hESC$\mathrm{CMs}^{[173]}$. Interestingly, we could identify a clotrimazole- and TRAM-34-sensitive $\mathrm{K}^{+}$current $^{[173]}$. These two SK4 channel antagonists induced a depolarization of the MDP and a reversible cessation of the automaticity. Notably, the $\mathrm{APD}_{50}$ of the cell was not prolonged, suggesting that this conductance was not involved in the repolarization of the AP but rather was involved in the prolongation of the diastolic depolarization period $^{[173]}$. This current was identified as an $I_{\mathrm{KCa}}$ conductance

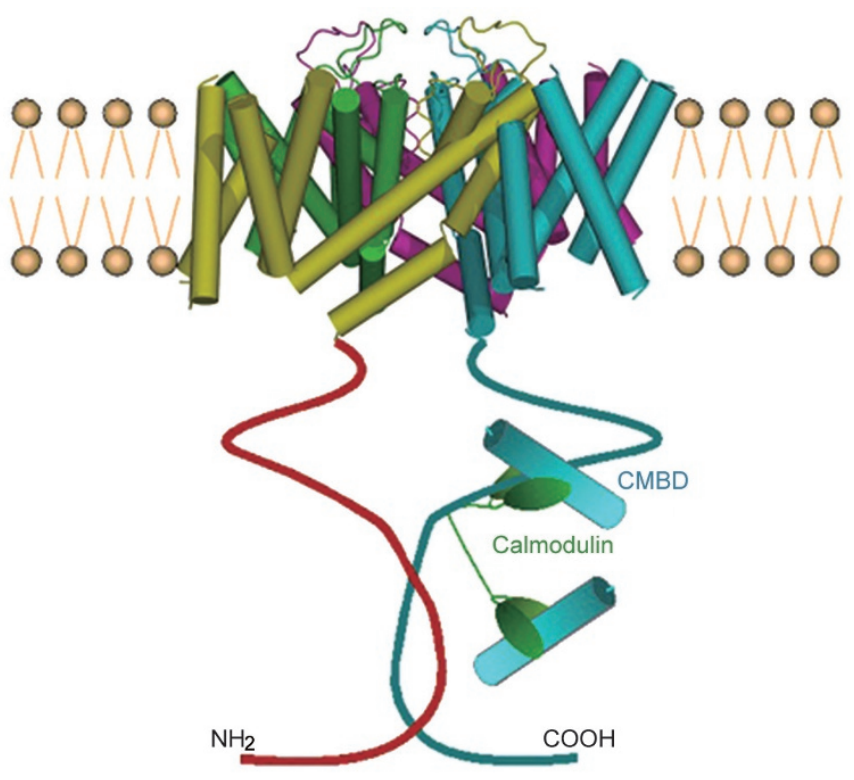

Figure 4. Representative cartoon of an SK4 $\alpha$-subunit. Each subunit is formed by six transmembrane domains (S1 to S6) with extended cytoplasmic $\mathrm{N}$ - and $\mathrm{C}$-termini. S4 is the voltage sensor with few positively charged amino acids. The segment (P-loop) between S5 and S6 forms the pore and includes the "selectivity filter" motif for potassium channels. The $\mathrm{N}$-terminus of one subunit and the $\mathrm{C}$-terminus of an adjacent subunit are shown. The calmodulin binding domain (CMBD) binds $\mathrm{Ca}^{2+}-$ Calmodulin, which is necessary for SK4 channel gating.

at the whole-cell current level and also at the single channel level (TRAM 34-sensitive unitary current) with a unitary slope conductance of approximately $21 \mathrm{pS}$, a value within the range (between 10 to $42 \mathrm{pS}$ ) observed for intermediate calcium-activated potassium channels ${ }^{[163]}$. The molecular identity of the SK4/KCa3.1 channel was confirmed by performing RT-PCR and Western blot analyses on young cardiomyocytes derived from two independent hES lines ${ }^{[173]}$. Immunocytochemistry for SK4 and a-actinin, a cardiac marker, showed that both proteins were coexpressed in the same cells. Blocking SK4 led to a fast depolarization drift of the MDP and a cessation of the pacing, similar to what was observed when the prominent pacemaker inward current was blocked ${ }^{[173]}$.

Thus, if $I_{\mathrm{KCa}}$ is not involved in the repolarization phase of the APs, what is its plausible role in the pacemaker and how does $I_{\mathrm{KCa}}$ inhibition account for the MDP depolarization? We hypothesize that as an outward current, $I_{\mathrm{KCa}}$ contributes to the MDP driving force by activating the funny current and subtly balancing the inward current of the NCX exchanger during diastolic depolarization. Indeed, $I_{\mathrm{KCa}}$ could "shape" the diastolic slope to the intracellular calcium concentration by opposing its outward current to the two depolarizing conductances, $I_{\mathrm{f}}$ and NCX. Whereas the SK1-3 channels have a low affinity for $\left[\mathrm{Ca}^{2+}\right]_{i}$ activation (half activation between 300 to $700 \mathrm{nmol} / \mathrm{L}$ free $\left.\mathrm{Ca}^{2+}\right)^{[136,137,139]}$, the SK4 channels exhibit a half activation at $95 \mathrm{nmol} / \mathrm{L}$ intracellular free $\mathrm{Ca}^{2+}$, a concentration that is very close to the physiological diastolic $\left[\mathrm{Ca}^{2+}\right]_{\mathrm{i}}$ level ${ }^{[155]}$. 
In guinea pig SAN cells, the minimal diastolic $\left[\mathrm{Ca}^{2+}\right]_{\mathrm{i}}$ concentration was found to be $225 \mathrm{nmol} / \mathrm{L}^{[179]}$, a value that makes the SK4 channels ideally suited for a role at the DD slope period. At the end of the repolarization, the intracellular free calcium concentrations are sufficiently high to activate the SK4 channels (Figure 5).

According to our model, we postulate that the SK4 outward potassium current, which is responsible for the notch of the MDP, provides a driving force that is sufficiently strong to activate $I_{\mathrm{f}}$ at the early phase of the DD slope (Figure 5). The progressive sodium inflow is accompanied by a calcium outflow where NCX operates in its forward mode. The progressive decrease in the intracellular $\mathrm{Ca}^{2+}$ concentrations gradually weaken the SK4 $\mathrm{K}^{+}$current and allow the $I_{\mathrm{f}}$ and/or $I_{\mathrm{NCX}}$ depolarizing inward currents to take over until the threshold for a novel AP is achieved. By contrast, SK4 blockade with drugs such as clotrimazole or TRAM-34 remove the outward current necessary for the DD slope gradient, eventually suppressing the pacing.

How can we explain the depolarizing drift observed after $I_{\mathrm{f}}$ or $I_{\mathrm{NCX}}$ blockade? Several studies showed that a blockade of $I_{\mathrm{f}}$ by ZD7288 or ivabradine was associated with a reduction in the intracellular calcium sparks. These observations were made in mouse embryonic (E8-E9) cardiomyocytes ${ }^{[180]}$, in cardiomyocytes isolated from the rabbit pulmonary vein ${ }^{[181]}$, and in rabbit SAN cells ${ }^{[182]}$. One can assume that the decreased

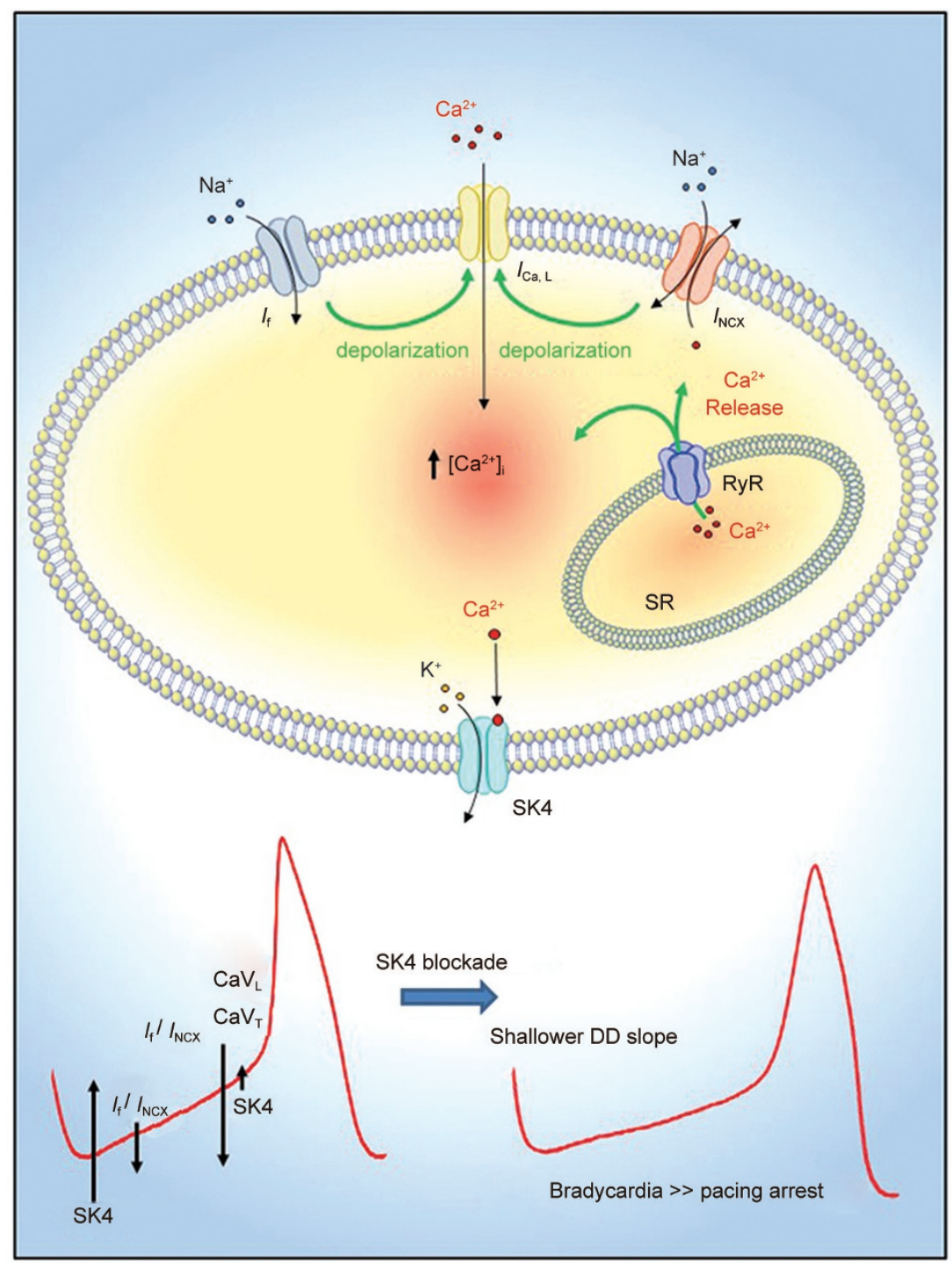

Figure 5. Pacemaker model of human embryonic stem cell-derived cardiomyocytes (adapted from Weisbrod et al, 2013, Ref [173]). During the early phase of DD there is enough intracellular free $\left[\mathrm{Ca}^{2+}\right]_{i}$ to activate the SK4 channels $\left(I_{K C a}\right)$, which contributes to the MDP driving force and concurrently activates $I_{\mathrm{f}}$. The $I_{\mathrm{f}}$ and NCX currents triggered by the cyclical $\mathrm{Ca}^{2+}$ release from the sarcoplasmic reticulum (SR) depolarize the membrane to activate the L-type $\mathrm{Ca}^{2+}$ channels $\left(I_{\mathrm{Ca}, \mathrm{L}}\right)$ and cause AP cycling. The progressive decrease in $\left[\mathrm{Ca}^{2+}\right]_{\mathrm{i}}$ from early to late DD mediated by the NCX-induced Ca ${ }^{2+}$ outflow gradually reduces the $I_{\text {KCa }}$ currents and allows the inward currents to take over and reach the next AP threshold. Thus, the SK4 channels ( $\left.I_{\mathrm{KCa}}\right)$ finely tune the inward currents of the "voltage" and $\mathrm{Ca}^{2+}$ clocks and have a crucial role in shaping the DD and the pacemaker activity. 
$\mathrm{Na}^{+}$influx upon $I_{\mathrm{f}}$ blockade stimulates the forward mode of the NCX exchanger and thereby enhances $\mathrm{Ca}^{2+}$ outflow to ultimately reduce the DD cytosolic $\left[\mathrm{Ca}^{2+}\right]_{\mathrm{i}}$. The decreased $\left[\mathrm{Ca}^{2+}\right]_{\mathrm{i}}$ eventually inhibits the $I_{\mathrm{KCa}}$, which, together with the enhanced electrogenic activity of NCX, depolarizes the MDP and inhibit the APs. By contrast, $I_{\mathrm{NCX}}$ inhibition with equimolar replacement of the external sodium with lithium is accompanied by a reduction in the cytosolic $\left[\mathrm{Ca}^{2+}\right]_{\mathrm{i}}^{[179]}$. Similarly, we suggest that NCX blockade (eg, by KB-R7943 and FRCRCFa) prevents the depolarizing electrogenic activity of NCX and the subsequent activation of the L-type $\mathrm{Ca}^{2+}$ channels operating at the late DD period. This action ultimately reduces the DD cytosolic $\left[\mathrm{Ca}^{2+}\right]_{\mathrm{i}}$, thereby leading to $I_{\mathrm{KCa}}$ closure, MDP depolarization, and the suppression of pacemaker activity.

\section{Future direction}

SK4 transcripts are expressed in the mouse SAN, adult human right atrium and in ventricular biopsies. Furthermore, the expression of the SK4 protein is restricted to the human right atrium (unpublished data). Similar to the hESC-CMs, we also identified TRAM34-sensitive SK4 currents in the mouse SAN (unpublished data). Overall, our data are consistent with recent studies showing that the SK4 channels are critical players in determining the cardiac pacemaker fate in embryonic stem cells and induced pluripotent stem cells from mice ${ }^{[183-185]}$ and humans ${ }^{[186]}$. Treatment with 1-ethyl-2-benzimidazolinone (EBIO), the SK4 channel opener, differentiates mouse embryonic stem cells into cardiomyocytes, with a strong enrichment of the pacemaker-like cells ${ }^{[183]}$. This differentiation is accompanied by the induction of SAN-specific genes and by a loss of the ventricular-specific gene program ${ }^{[183]}$. Notably, the SK4 channel blocker clotrimazole inhibits EBIO-induced cardiogenesis and the up-regulation of the pacemaker transcripts ${ }^{[183]}$. In addition, a transcriptional analysis showed a ninefold upregulation of the SK4 mRNA in the developing conduction system compared with SK1-3 ${ }^{[187]}$. In future studies, it will be crucial to demonstrate the presence of the SK4 channels in mammalian SAN cells, including humans, and their involvement in the maintenance of the cardiac pacemaker. More importantly, the role of SK4 channels should be investigated in idiopathic sinus arrhythmias and also in all cardiac disorders that manifest an impaired sinus rhythm.

\section{Acknowledgements}

This work was supported by the Israel Science Foundation (ISF 1215/13 and 2092/14) and the Fields Fund for Cardiovascular Research. Bernard ATTALI holds the Andy Libach Professorial Chair in Clinical Pharmacology and Toxicology.

\section{References}

1 Christoffels VM, Smits GJ, Kispert A, Moorman AF. Development of the pacemaker tissues of the heart. Circ Res 2010; 106: 240-54.

2 Vicente-Steijn R, Passier R, Wisse L, Schalij MJ, Poelmann RE, Gittenberger-de Groot AC, et al. Funny current channel HCN4 delineates the developing cardiac conduction system in chicken heart. Heart Rhythm 2011; 8: 1254-63.
3 Später D, Abramczuk MK, Buac K, Zangi L, Stachel MW, Clarke J, Sahara $\mathrm{M}$, et al. A HCN4 ${ }^{+}$cardiomyogenic progenitor derived from the first heart field and human pluripotent stem cells. Nat Cell Biol 2013; 15: 1098-106.

4 Kreuzberg MM, Söhl G, Kim JS, Verselis VK, Willecke K, Bukauskas FF. Functional properties of mouse connexin30.2 expressed in the conduction system of the heart. Circ Res 2005; 96: 1169-77.

5 Kreuzberg MM, Liebermann M, Segschneider S, Dobrowolski R, Dobrzynski H, Kaba R, et al. Human connexin31.9, unlike its orthologous protein connexin30.2 in the mouse, is not detectable in the human cardiac conduction system. J Mol Cell Cardiol 2009; 46: 553-9.

6 Bakker ML, Boukens BJ, Mommersteeg MT, Brons JF, Wakker V, Moorman AF, et al. Transcription factor Tbx3 is required for the specification of the atrioventricular conduction system. Circ Res 2008; 102: 1340-9.

7 Satin J, Fujii S, DeHaan RL. Development of cardiac beat rate in early chick embryos is regulated by regional cues. Develop Biol 1988; 129: 103-13.

8 Wenink ACG. Development of the human cardiac conducting system. J Anat 1976; 121: 617-31.

9 Lieberman M, Paes de Carvalho A. The electrophysiological organization of the embryonic chick heart. J Gen Physiol 1965; 49: 351-63.

10 Argüello C, Alanís J, Pantoja O, Valenzuela B. Electrophysiological and ultrastructural study of the atrioventricular canal during the development of the chick embryo. J Mol Cell Cardiol 1986; 18: 499510.

11 Hoogaars WM, Tessari A, Moorman AF, de Boer PA, Hagoort J, Soufan AT, et al. The transcriptional repressor Tbx3 delineates the developing central conduction system of the heart. Cardiovasc Res 2004; 62: 489-99.

12 Hoogaars WMH, Barnett P, Moorman AFM, Christoffels VM. Cardiovascular development: towards biomedical applicability. Cell Mol Life Sci 2007; 64: 646-60.

13 Moorman AFM, Christoffels VM. Cardiac chamber formation: development, genes, and evolution. Physiol Rev 2003; 83: 1223-67.

14 Jansen JA, van Veen TAB, de Bakker JMT, van Rijen HVM. Cardiac connexins and impulse propagation. J Mol Cell Cardiol 2010; 48: 76-82.

15 Remme CA, Verkerk AO, Hoogaars WM, Aanhaanen WT, Scicluna BP, Annink $C$, et al. The cardiac sodium channel displays differential distribution in the conduction system and transmural heterogeneity in the murine ventricular myocardium. Basic Res Cardiol 2009; 104: 511-22.

16 Yasui K, Liu W, Opthof T, Kada K, Lee JK, Kamiya K, et al. If current and spontaneous activity in mouse embryonic ventricular myocytes. Circ Res 2001; 88: 536-42.

17 Couette B, Marger L, Nargeot J, Mangoni ME. Physiological and pharmacological insights into the role of ionic channels in cardiac pacemaker activity. Cardiovasc Hematol Disord Drug Targets 2006; 6: 169-90.

18 Bakker ML, Christoffels VM, Moorman AFM. The cardiac pacemaker and conduction system develops from embryonic myocardium that retains its primitive phenotype. J Cardiovasc Pharmacol 2010; 56: 6-15.

19 Virágh S, Challice CE. The development of the conduction system in the mouse embryo heart: I. The first embryonic A-V conduction pathway. Develop Biol 1977; 56: 382-96.

20 Virágh S, Challice CE. The development of the conduction system in the mouse embryo heart: II. Histogenesis of the atrioventricular node and bundle. Develop Biol 1977; 56: 397-411. 
21 Gourdie RG, Harris BS, Bond J, Justus C, Hewett KW, O'Brien TX, et al. Development of the cardiac pacemaking and conduction system. Birth Defects Res C Embryo Today 2003; 69: 46-57.

22 Mommersteeg MT, Hoogaars WM, Prall OW, de Gier-de Vries C, Wiese $\mathrm{C}$, Clout DE, et al. Molecular pathway for the localized formation of the sinoatrial node. Circ Res 2007; 100: 354-62.

23 Christoffels VM, Mommersteeg MT, Trowe MO, Prall OW, de Gier-de Vries C, Soufan AT, et al. Formation of the venous pole of the heart from an NKX2-5-negative precursor population requires Tbx18. Circ Res 2006; 98: 1555-63.

24 Blom NA, Gittenberger-de Groot AC, DeRuiter MC, Poelmann RE, Mentink MM, Ottenkamp J. Development of the cardiac conduction tissue in human embryos using HNK-1 antigen expression: possible relevance for understanding of abnormal atrial automaticity. Circulation 1999; 99: 800-6.

25 Dickinson DF, Wilkinson JL, Anderson KR, Smith A, Ho SY, Anderson $\mathrm{RH}$. The cardiac conduction system in situs ambiguus. Circulation 1979; 59: 879-85.

26 Christoffels VM, Moorman AFM. Development of the cardiac conduction system: why are some regions of the heart more arrhythmogenic than others? Circ Arrhythm Electrophysiol 2009; 2: 195-207.

27 Moorman AFM, de Jong F, Denyn MMFJ, Lamers WH. Development of the cardiac conduction system. Circ Res 1998; 82: 629-44.

28 Atkinson A, Inada S, Li J, Tellez JO, Yanni J, Sleiman R, et al. Anatomical and molecular mapping of the left and right ventricular His-Purkinje conduction networks. J Mol Cell Cardiol 2011; 51: 689-701.

29 Mangoni ME, Nargeot J. Genesis and regulation of the heart automaticity. Physiol Rev 2008; 88: 919-82.

30 Brown HF, Difrancesco D, Noble SJ. How does adrenaline accelerate the heart? Nature 1979; 280: 235-6.

31 Brown H, Difrancesco D. Voltage-clamp investigations of membrane currents underlying pace-maker activity in rabbit sino-atrial node. J Physiol 1980; 308: 331-51.

32 Brown HF, Clark A, Noble SJ. Identification of the pace-maker current in frog atrium. J Physiol 1976; 258: 521-45.

33 Difrancesco D, Ojeda C. Properties of the current $l_{f}$ in the sino-atrial node of the rabbit compared with those of the current $I_{\mathrm{K}}$, in Purkinje fibres. J Physiol 1980; 308: 353-67.

34 Baruscotti M, Barbuti A, Bucchi A. The cardiac pacemaker current. J Mol Cell Cardiol 2010; 48: 55-64.

35 Giorgetti A, Carloni P, Mistrik P, Torre V. A homology model of the pore region of HCN channels. Biophys J 2005; 89: 932-44.

36 Michels G, Brandt MC, Zagidullin N, Khan IF, Larbig R, van Aaken S, et al. Direct evidence for calcium conductance of hyperpolarizationactivated cyclic nucleotide-gated channels and human native $I_{\mathrm{f}}$ at physiological calcium concentrations. Cardiovasc Res 2008; 78 : 466-75.

37 Baruscotti M, Bottelli G, Milanesi R, DiFrancesco J, DiFrancesco D. HCN-related channelopathies. Pflügers Arch Eur J Physiol 2010; 460: 405-15.

38 Garcia-Frigola C, Shi Y, Evans SM. Expression of the hyperpolarization-activated cyclic nucleotide-gated cation channel HCN4 during mouse heart development. Gene Expression Patterns 2003; 3: $777-83$.

39 Stieber J, Hofmann F, Ludwig A. Pacemaker channels and sinus node arrhythmia. Trends Cardiovasc Med 2004; 14: $23-8$.

40 Fenske S, Mader R, Scharr A, Paparizos C, Cao-Ehlker X, Michalakis S, et al. HCN3 contributes to the ventricular action potential waveform in the murine heart. Circ Res 2011; 109: 1015-23.

41 Hoppe UC, Beuckelmann DJ. Characterization of the hyperpolarization-activated inward current in isolated human atrial myocytes. Car- diovasc Res 1998; 38: 788-801.

42 Verkerk AO, Wilders R, van Borren MM, Peters RJ, Broekhuis E, Lam K, et al. Pacemaker current $\left(I_{f}\right)$ in the human sinoatrial node. Eur Heart J 2007; 28: 2472-8.

$43 \mathrm{Yu} \mathrm{H}$, Wu J, Potapova I, Wymore RT, Holmes B, Zuckerman J, et al. MinK-related peptide 1: A $\beta$ subunit for the HCN ion channel subunit family enhances expression and speeds activation. Circ Res 2001; 88: e84-e87.

44 Qu J, Kryukova Y, Potapova IA, Doronin SV, Larsen M, Krishnamurthy G, et al. MiRP1 modulates HCN2 channel expression and gating in cardiac myocytes. J Biol Chem 2004; 279: 43497-502.

45 Decher N, Bundis F, Vajna R, Steinmeyer K. KCNE2 modulates current amplitudes and activation kinetics of HCN4: influence of KCNE family members on HCN4 currents. Pflügers Arch 2003; 446: 633-40.

46 Pian P, Bucchi A, Robinson RB, Siegelbaum SA. Regulation of gating and rundown of HCN hyperpolarization-activated channels by exogenous and endogenous PIP2. J Gen Physiol 2006; 128: 593-604.

47 Zong X, Eckert C, Yuan H, Wahl-Schott C, Abicht H, Fang L, et al. A novel mechanism of modulation of hyperpolarization-activated cyclic nucleotide-gated channels by src kinase. J Biol Chem 2005; 280 : 34224-32.

$48 \mathrm{Yu} \mathrm{H}$, Chang, F, Cohen IS. Phosphatase inhibition by calyculin A increases $I_{\mathrm{f}}$ in canine Purkinje fibers and myocytes. Pflugers Arch 1993; 422: 614-6.

49 Accili EA, Redaelli G, DiFrancesco D. Differential control of the hyperpolarization-activated current $\left(I_{f}\right)$ by cAMP gating and phosphatase inhibition in rabbit sino-atrial node myocytes. J Physiol 1997; 500: 643-51.

50 Yeh YH, Burstein B, Qi XY, Sakabe M, Chartier D, Comtois P, et al. Funny current downregulation and sinus node dysfunction associated with atrial tachyarrhythmia: a molecular basis for tachycardiabradycardia syndrome. Circulation 2009; 119: 1576-85.

51 Stieber J, Herrmann S, Feil S, Löster J, Feil R, Biel M, et al. The hyperpolarization-activated channel HCN4 is required for the generation of pacemaker action potentials in the embryonic heart. Proc Natl Acad Sci U S A 2003; 100: 15235-40.

52 Herrmann S, Stieber J, Stöckl G, Hofmann F, Ludwig A. HCN4 provides a 'depolarization reserve' and is not required for heart rate acceleration in mice. EMBO J 2007; 26: 4423-32.

53 Denyer JC, Brown HF. Pacemaking in rabbit isolated sino-atrial node cells during $\mathrm{Cs}^{+}$block of the hyperpolarization-activated current $I_{\mathrm{f}}$. J Physiol 1990; 429: 401-9.

54 Hagiwara N, Irisawa H, Kasanuki H, Hosoda S. Background current in sino-atrial node cells of the rabbit heart. J Physiol 1992; 448: 53-72.

55 Guo J, Ono K, Noma A. Monovalent cation conductance of the sustained inward current in rabbit sinoatrial node cells. Pflügers Arch 1996; 433: 209-11.

56 Guo J, Ono K, Noma A. A sustained inward current activated at the diastolic potential range in rabbit sino-atrial node cells. J Physiol 1995; 483: 1-13.

57 Guo J, Mitsuiye T, Noma A. The sustained inward current in sino-atrial node cells of guinea-pig heart. Pflügers Arch 1997; 433: 390-6.

58 Shinagawa $\mathrm{Y}$, Satoh H, Noma A. The sustained inward current and inward rectifier $\mathrm{K}^{+}$current in pacemaker cells dissociated from rat sinoatrial node. J Physiol 2000; 523: 593-605.

59 Hagiwara N, Irisawa H, Kameyama M. Contribution of two types of calcium currents to the pacemaker potentials of rabbit sino-atrial node cells. J Physiol 1988; 395: 233-53.

60 Hirano Y, Fozzard HA, January CT. Characteristics of L- and T-type $\mathrm{Ca}^{2+}$ currents in canine cardiac Purkinje cells. Am J Physiol 1989; 
256: H1478-92.

61 Christel CJ, Cardona N, Mesirca P, Herrmann S, Hofmann F, Striessnig J, et al. Distinct localization and modulation of Cav1.2 and Cav1.3 Ltype $\mathrm{Ca}^{2+}$ channels in mouse sinoatrial node. J Physiol 2012; 590: 6327-41.

62 Cribbs L. T-type calcium channel expression and function in the diseased heart. Channels 2010; 4: 447-52.

63 Mesirca P, Torrente A, Mangoni M. T-type channels in the sino-atrial and atrioventricular pacemaker mechanism. Pflügers Arch Eur J Physiol 2014; 466: 791-9.

64 Mangoni ME, Traboulsie A, Leoni AL, Couette B, Marger L, Le Quang K, et al. Bradycardia and slowing of the atrioventricular conduction in mice lacking CaV3.1/ $\alpha 1 \mathrm{G}$ T-type calcium channels. Circ Res 2006; 98: 1422-30.

65 Mangoni ME, Couette B, Bourinet E, Platzer J, Reimer D, Striessnig J, et al. Functional role of L-type Cav1.3 $\mathrm{Ca}^{2+}$ channels in cardiac pacemaker activity. Proc Natl Acad Sci U S A 2003; 100: 5543-8.

66 Zhang Z, Xu Y, Song H, Rodriguez J, Tuteja D, Namkung Y, et al. Functional roles of Cav1.3 $(\alpha 1 D)$ calcium channel in sinoatrial nodes: insight gained using gene-targeted null mutant mice. Circ Res 2002; 90: 981-7.

67 Zhang Q, Timofeyev V, Qiu H, Lu L, Li N, Singapuri A, et al. Expression and roles of Cav1.3 ( $\alpha 1 \mathrm{D})$ L-Type $\mathrm{Ca}^{2+}$ Channel in atrioventricular node automaticity. J Mol Cell Cardiol 2011; 50: 194-202.

68 Platzer J, Engel J, Schrott-Fischer A, Stephan K, Bova S, Chen H, et al. Congenital deafness and sinoatrial node dysfunction in mice lacking class D L-type $\mathrm{Ca}^{2+}$ channels. Cell 2000; 102: 89-97.

69 Demion M, Bois P, Launay P, Guinamard R. TRPM4, a Ca ${ }^{2+}$-activated nonselective cation channel in mouse sino-atrial node cells. Cardiovasc Res 2007; 73: 531-8.

70 Hof T, Simard C, Rouet R, Sallé L, Guinamard R. Implication of the TRPM4 nonselective cation channel in mammalian sinus rhythm. Heart Rhythm 2013; 10: 1683-9.

71 Little SC, Mohler PJ. TRPM4 modulates sinus node diastolic depolarization. Heart Rhythm 2013; 10: 1690-1.

72 Sah R, Mesirca P, Mason X, Gibson W, Bates-Withers C, Van den Boogert M, et al. Timing of myocardial TRPM7 deletion during cardiogenesis variably disrupts adult ventricular function, conduction, and repolarization. Circulation 2013; 128: 101-14.

73 Sah R, Mesirca P, Van den Boogert M, Rosen J, Mably J, Mangoni ME, et al. Ion channel-kinase TRPM7 is required for maintaining cardiac automaticity. Proc Natl Acad Sci U S A 2013; 110: E3037-E3046.

74 Noma A, Trautwein W. Relaxation of the ACh-induced potassium current in the rabbit sinoatrial node cell. Pflugers Arch 1978; 377 : 193-200.

75 DiFrancesco D, Ducouret P, Robinson RB. Muscarinic modulation of cardiac rate at low acetylcholine concentrations. Science 1989; 243: 669-71.

76 Han X, Light PE, Giles WR, French RJ. Identification and properties of an ATP-sensitive $\mathrm{K}^{+}$current in rabbit sino-atrial node pacemaker cells. J Physiol 1996; 490: 337-50.

77 Tamargo J, Caballero R, Gómez R, Valenzuela C, Delpón E. Pharmacology of cardiac potassium channels. Cardiovasc Res 2004; 62: 9-33.

78 Fabiato A, Fabiato F. Excitation-contraction coupling of isolated cardiac fibers with disrupted or closed sarcolemmas: calcium-dependent cyclic and tonic contractions. Circ Res 1972; 31: 293-307.

79 Niedergerke R. Calcium and the activation of contraction. Experientia 1959; 15: 128-30.

80 Reichel $\mathrm{H}$, Bleichert A. Excitation-contraction coupling in heart muscle. Nature 1959; 183: 826-7.
81 Brooks CM, Winegrad S. The possible role of calcium in excitationcontraction coupling of heart muscle. Circulation 1961; 24: 523-9.

82 Capogrossi MC, Lakatta EG. Frequency modulation and synchronization of spontaneous oscillations in cardiac cells. Am J Physiol 1985; 248: H412-8.

83 Stern MD, Capogrossi MC, Lakatta EG. Spontaneous calcium release from the sarcoplasmic reticulum in myocardial cells: mechanisms and consequences. Cell Calcium 1988; 9: 247-56.

84 Wier WG, Kort AA, Stern MD, Lakatta EG, Marban E. Cellular calcium fluctuations in mammalian heart: direct evidence from noise analysis of aequorin signals in Purkinje fibers. Proc Natl Acad Sci U S A 1983; 80: $7367-71$.

85 Lakatta EG, Talo A, Capogrossi MC, Spurgeon HA, Stern MD. In: Holtz J, Drexler $\mathrm{H}$, Just $\mathrm{H}$, editors. Cardiac adaptation in heart failure. NewYork: Springer; 1992. Ch9, p 93-104.

86 Bassani RA, Bassani JW, Lipsius SL, Bers DM. Diastolic SR Ca efflux in atrial pacemaker cells and Ca-overloaded myocytes. Am J Physiol 1997; 273: H886-92.

87 Vinogradova TM, Zhou YY, Maltsev V, Lyashkov A, Stern M, Lakatta EG. Rhythmic ryanodine receptor $\mathrm{Ca}^{2+}$ releases during diastolic depolarization of sinoatrial pacemaker cells do not require membrane depolarization. Circ Res 2004; 94: 802-9.

88 Rigg L, Terrar D. Possible role of calcium release from the sarcoplasmic reticulum in pacemaking in guinea-pig sino-atrial node. Exp Physiol 1996; 81: 877-80.

89 Zhou Z, Lipsius SL. $\mathrm{Na}^{+}-\mathrm{Ca}^{2+}$ exchange current in latent pacemaker cells isolated from cat right atrium. J Physiol 1993; 466: 263-85.

90 Huser J, Blatter LA, Lipsius SL. Intracellular $\mathrm{Ca}^{2+}$ release contributes to automaticity in cat atrial pacemaker cells. J Physiol 2000; 524 Pt 2: 415-22.

91 Bogdanov KY, Vinogradova TM, Lakatta EG. Sinoatrial nodal cell ryanodine receptor and $\mathrm{Na}^{+}-\mathrm{Ca}^{2+}$ exchanger: molecular partners in pacemaker regulation. Circ Res 2001; 88: 1254-8.

92 Maltsev VA, Vinogradova TM, Lakatta EG. The emergence of a general theory of the initiation and strength of the heart beat. J Pharmacol Sci 2006; 100: 338-69.

93 Maltsev VA, Lakatta EG. Normal heart rhythm is initiated and regulated by an intracellular calcium clock within pacemaker cells. Heart Lung Circ 2007; 16: 335-48.

94 Vinogradova TM, Lyashkov AE, Zhu W, Ruknudin AM, Sirenko S, Yang D, et al. High basal protein kinase A-dependent phosphorylation drives rhythmic internal $\mathrm{Ca}^{2+}$ store oscillations and spontaneous beating of cardiac pacemaker cells. Circ Res 2006; 98: 505-14.

95 Zhou P, Zhao YT, Guo YB, Xu SM, Bai SH, Lakatta EG, et al. Betaadrenergic signaling accelerates and synchronizes cardiac ryanodine receptor response to a single L-type $\mathrm{Ca}^{2+}$ channel. Proc Natl Acad Sci U S A 2009; 106: 18028-33.

96 Vinogradova TM, Lakatta EG. Regulation of basal and reserve cardiac pacemaker function by interactions of cAMP-mediated PKAdependent $\mathrm{Ca}^{2+}$ cycling with surface membrane channels. J Mol Cell Cardiol 2009; 47: 456-74.

97 Ginsburg KS, Bers DM. Isoproterenol does not enhance Ca-dependent $\mathrm{Na} / \mathrm{Ca}$ exchange current in intact rabbit ventricular myocytes. J Mol Cell Cardiol 2005; 39: 972-81.

98 Yang $D^{1}$, Zhu WZ, Xiao B, Brochet DX, Chen SR, Lakatta EG, et al. $\mathrm{Ca}^{2+} /$ Calmodulin kinase II-dependent phosphorylation of ryanodine receptors suppresses $\mathrm{Ca}^{2+}$ sparks and $\mathrm{Ca}^{2+}$ waves in cardiac myocytes. Circ Res 2007; 100: 399-407.

99 Blayney LM, Lai FA. Ryanodine receptor-mediated arrhythmias and sudden cardiac death. Pharmacol Ther 2009; 123: 151-77.

100 Bround MJ, Asghari P, Wambolt RB, Bohunek L, Smits C, Philit M, et 
al. Cardiac ryanodine receptors control heart rate and rhythmicity in adult mice. Cardiovasc Res 2012; 96: 372-80.

101 Koushik SV, Wang J, Rogers R, Moskophidis D, Lambert NA, Creazzo $\mathrm{TL}$, et al. Targeted inactivation of the sodium-calcium exchanger (Ncx1) results in the lack of a heart beat and abnormal myofibrillar organization. FASEB J 2001; 15: 1209-11.

102 Groenke S, Larson ED, Alber S, Zhang R, Lamp ST, Ren X, et al. Complete atrial-specific knockout of sodium-calcium exchange eliminates sinoatrial node pacemaker activity. PLoS One 2013; 8: e81633.

103 Herrmann S, Lipp P, Wiesen K, Stieber J, Nguyen H, Kaiser E, et al. The cardiac sodium-calcium exchanger NCX1 is a key player in the initiation and maintenance of a stable heart rhythm. Cardiovasc Res 2013; 99: 780-8.

104 Gao Z, Chen B, Joiner ML, Wu Y, Guan X, Koval OM, et al. I(f) and SR $\mathrm{Ca}^{2+}$ release both contribute to pacemaker activity in canine sinoatrial node cells. J Mol Cell Cardiol 2010; 49: 33-40.

105 Honjo H, Inada S, Lancaster MK, Yamamoto M, Niwa R, Jones SA, et al. Sarcoplasmic reticulum $\mathrm{Ca}^{2+}$ release is not a dominating factor in sinoatrial node pacemaker activity. Circ Res 2003; 92: e41-e44.

106 Lakatta EG, DiFrancesco D. What keeps us ticking: a funny current, a calcium clock, or both? J Mol Cell Cardiol 2009; 47: 157-70.

107 Lakatta EG, Maltsev VA, Vinogradova TM. A coupled system of intracellular $\mathrm{Ca}^{2+}$ clocks and surface membrane voltage clocks controls the timekeeping mechanism of the heart's pacemaker. Circ Res 2010; 106: 659-73.

108 Zahanich I, Sirenko SG, Maltseva LA, Tarasova YS, Spurgeon HA, Boheler KR, et al. Rhythmic beating of stem cell-derived cardiac cells requires dynamic coupling of electrophysiology and Ca cycling. J Mol Cell Cardiol 2010; 50: 66-76.

109 Billman GE. Does the 'coupled clock' make the heart tick? Cardiovasc Res 2012; 96: 343-4.

110 Verkerk AO, van Borren MM, Wilders R. Calcium transient and sodium-calcium exchange current in human versus rabbit sinoatrial node pacemaker cells. ScientificWorldJournal 2013; 2013: 507872. doi: 10.1155/2013/507872.

111 Thomson JA, Itskovitz-Eldor J, Shapiro SS, Waknitz MA, Swiergiel JJ, Marshall VS, et al. Embryonic stem cell lines derived from human blastocysts. Science 1998; 282: 1145-7.

112 Itskovitz-Eldor J, Schuldiner M, Karsenti D, Eden A, Yanuka O, Amit M, et al. Differentiation of human embryonic stem cells into embryoid bodies compromising the three embryonic germ layers. Mol Med 2000; 6: 88-95.

113 Satin J, Kehat I, Caspi O, Huber I, Arbel G, Itzhaki I, et al. Mechanism of spontaneous excitability in human embryonic stem cell derived cardiomyocytes. J Physiol 2004; 559: 479-96.

114 Itzhaki I, Schiller J, Beyar R, Satin J, Gepstein L. Calcium handling in embryonic stem cell-derived cardiac myocytes. Ann N Y Acad Sci 2006; 1080: 207-15.

115 Laflamme MA, Chen KY, Naumova AV, Muskheli V, Fugate JA, Dupras SK, et al. Cardiomyocytes derived from human embryonic stem cells in pro-survival factors enhance function of infarcted rat hearts. Nat Biotech 2007; 25: 1015-24.

116 Shiba Y, Fernandes S, Zhu WZ, Filice D, Muskheli V, Kim J, et al. Human ES-cell-derived cardiomyocytes electrically couple and suppress arrhythmias in injured hearts. Nature 2012; 489: 322-5.

117 Chong JJ, Yang X, Don CW, Minami E, Liu YW, Weyers JJ, et al. Human embryonic-stem-cell-derived cardiomyocytes regenerate nonhuman primate hearts. Nature 2014; 510: 273-7.

118 He JQ, Ma Y, Lee Y, Thomson JA, Kamp TJ. Human embryonic stem cells develop into multiple types of cardiac myocytes: action potential characterization. Circ Res 2003; 93: 32-9.
119 Reppel M, Pillekamp F, Brockmeier K, Matzkies M, Bekcioglu A, Lipke $\mathrm{T}$, et al. The electrocardiogram of human embryonic stem cell-derived cardiomyocytes. J Electrocardiol 2005; 38: 166-70.

120 Boheler KR, Czyz J, Tweedie D, Yang HT, Anisimov SV, Wobus AM. Differentiation of pluripotent embryonic stem cells into cardiomyocytes. Circ Res 2002; 91: 189-201.

121 Mummery C, van der Heyden MA, de Boer TP, Passier R, Ward D, van den Brink S, et al. Cardiomyocytes from human and mouse embryonic stem cells. Methods Mol Med 2007; 140: 249-72.

122 Zhu WZ, Van Biber B, Laflamme M. Human pluripotent stem cells .In: Schwartz PH, Wesselschmidt RL, editors. Vol 767. Methods in molecular biology. New York: Humana Press; 2011. Ch 31, p419-31.

123 Fu JD, Jiang P, Rushing S, Liu J, Chiamvimonvat N, Li RA. $\mathrm{Na}^{+} / \mathrm{Ca}^{2+}$ exchanger is a determinant of excitation-contraction coupling in human embryonic stem cell-derived ventricular cardiomyocytes. Stem Cells Dev 2010; 19: 773-82.

124 Hudson J, Titmarsh D, Hidalgo A, Wolvetang E, Cooper-White J. Primitive cardiac cells from human embryonic stem cells. Stem Cells Develop 2011; 21: 1513-23.

125 Scavone A, Capilupo D, Mazzocchi N, Crespi A, Zoia S, Campostrini G, et al. Embryonic stem cell-derived $\mathrm{CD}_{166^{+}}$precursors develop into fully functional sinoatrial-like cells. Circ Res 2013; 113: 389-98.

126 Vergara C, Latorre R, Marrion NV, Adelman JP. Calcium-activated potassium channels. Curr Opin Neurobiol 1998; 8: 321-9.

127 Heyer CB, Lux HD. Properties of a facilitating calcium current in pace-maker neurones of the snail, Helix pomatia. J Physiol 1976; 262: 319-48.

128 Atkinson NS, Robertson GA, Ganetzky B. A component of calciumactivated potassium channels encoded by the Drosophila slo locus. Science 1991; 253: 551-5.

129 Knaus HG, Garcia-Calvo M, Kaczorowski GJ, Garcia ML. Subunit composition of the high conductance calcium-activated potassium channel from smooth muscle, a representative of the mSlo and slowpoke family of potassium channels. J Biol Chem 1994; 269: 3921-4.

130 Jiang Z, Wallner M, Meera P, Toro L. Human and rodent MaxiK channel $\beta$-subunit genes: cloning and characterization. Genomics 1999; 55: 57-67.

131 Wallner M, Meera P, Toro L. Molecular basis of fast inactivation in voltage and $\mathrm{Ca}^{2+}$-activated $\mathrm{K}^{+}$channels: a transmembrane $\beta$-subunit homolog. Proc Natl Acad Sci U S A 1999; 96: 4137-42.

132 Knaus HG, Schwarzer C, Koch RO, Eberhart A, Kaczorowski GJ, Glossmann $\mathrm{H}$, et al. Distribution of high-conductance $\mathrm{Ca}^{2+}$-activated $\mathrm{K}^{+}$channels in rat brain: targeting to axons and nerve terminals. J Neurosci 1996; 16: 955-63.

133 Nelson MT, Cheng H, Rubart M, Santana LF, Bonev AD, Knot HJ, et al. Relaxation of arterial smooth muscle by calcium sparks. Science 1995; 270: 633-7.

134 Imlach WL, Finch SC, Miller JH, Meredith AL, Dalziel JE. A role for BK channels in heart rate regulation in rodents. PLoS One 2010; 5 : e8698.

135 Lai MH, Wu Y, Gao Z, Anderson ME, Dalziel JE, Meredith AL. BK channels regulate sinoatrial node firing rate and cardiac pacing in vivo. Am J Physiol Heart Circ Physio 2014; 307: H1327-1338.

136 Köhler M, Hirschberg B, Bond CT, Kinzie JM, Marrion NV, Maylie J, et al. Small-conductance, calcium-activated potassium channels from mammalian brain. Science 1996; 273: 1709-14.

137 Xia XM, Fakler B, Rivard A, Wayman G, Johnson-Pais T, Keen JE, et al. Mechanism of calcium gating in small-conductance calciumactivated potassium channels. Nature 1998; 395: 503-7.

138 Schumacher MA, Rivard AF, Bachinger HP, Adelman JP. Structure of the gating domain of a $\mathrm{Ca}^{2+}$-activated $\mathrm{K}^{+}$channel complexed with 
$\mathrm{Ca}^{2+}$ /calmodulin. Nature 2001; 410: 1120-4.

139 Park YB. Ion selectivity and gating of small conductance $\mathrm{Ca}^{2+}$-activated $\mathrm{K}^{+}$channels in cultured rat adrenal chromaffin cells. J Physiol 1994; 481: 555-70.

140 Lancaster B, Nicoll RA, Perkel DJ. Calcium activates two types of potassium channels in rat hippocampal neurons in culture. J Neurosci 1991; 11: 23-30.

141 Stocker M, Pedarzani P. Differential distribution of three $\mathrm{Ca}^{2+}$-activated $\mathrm{K}^{+}$channel subunits, SK1, SK2, and SK3, in the adult rat central nervous system. Mol Cell Neurosci 2000; 15: 476-93.

142 Pedarzani P, McCutcheon JE, Rogge G, Jensen BS, Christophersen P, Hougaard C, et al. Specific enhancement of SK channel activity selectively potentiates the afterhyperpolarizing current I(AHP) and modulates the firing properties of hippocampal pyramidal neurons. J Biol Chem 2005; 280: 41404-11.

143 Xu W, Liu Y, Wang S, McDonald T, Van Eyk JE, Sidor A, et al. Cytoprotective role of $\mathrm{Ca}^{2+}$ - activated $\mathrm{K}^{+}$channels in the cardiac inner mitochondrial membrane. Science 2002; 298: 1029-33.

144 Xu Y, Tuteja D, Zhang Z, Xu D, Zhang Y, Rodriguez J, et al. Molecular identification and functional roles of a $\mathrm{Ca}^{2+}$-activated $\mathrm{K}^{+}$channel in human and mouse hearts. J Biol Chem 2003; 278: 49085-94.

145 Tuteja D, Xu D, Timofeyev V, Lu L, Sharma D, Zhang Z, et al. Differential expression of small-conductance $\mathrm{Ca}^{2+}$-activated $\mathrm{K}^{+}$channels SK1, SK2, and SK3 in mouse atrial and ventricular myocytes. Am J Physiol Heart Circ Physiol2005; 289: H2714-2723.

146 Li N, Timofeyev V, Tuteja D, Xu D, Lu L, Zhang Q, et al. Ablation of a $\mathrm{Ca}^{2+}$-activated $\mathrm{K}^{+}$channel ( $\mathrm{SK} 2$ channel) results in action potential prolongation in atrial myocytes and atrial fibrillation. J Physiol 2009; 587: 1087-100.

147 Zhang Q, Timofeyev V, Lu L, Li N, Singapuri A, Long MK, et al. Functional roles of a $\mathrm{Ca}^{2+}$-activated $\mathrm{K}^{+}$channel in atrioventricular nodes. Circ Res 2008; 102: 465-71.

148 Qi XY, Diness JG, Brundel BJ, Zhou XB, Naud P, Wu CT, et al. Role of small-conductance calcium-activated potassium channels in atrial electrophysiology and fibrillation in the dog. Circulation 2014; 129 : 430-40.

149 Partiseti M, Choquet D, Diu A, Korn H. Differential regulation of voltage- and calcium-activated potassium channels in human $B$ lymphocytes. J Immunol 1992; 148: 3361-8.

150 Grissmer S, Nguyen AN, Cahalan MD. Calcium-activated potassium channels in resting and activated human $\mathrm{T}$ lymphocytes. Expression levels, calcium dependence, ion selectivity, and pharmacology. J Gen Physiol 1993; 102: 601-30.

151 Tuteja D, Rafizadeh S, Timofeyev V, Wang S, Zhang Z, Li N, et al. Cardiac small conductance $\mathrm{Ca}^{2+}$-activated $\mathrm{K}^{+}$channel subunits form heteromultimers via the coiled-coil domains in the $\mathrm{C}$ termini of the channels. Circ Res 2010; 107: 851-9.

152 Ghanshani S, Coleman M, Gustavsson P, Wu AC, Gargus JJ, Gutman GA, et al. Human calcium-activated potassium channel genekcnn4maps to chromosome 19q13.2 in the region deleted in diamond-blackfan anemia. Genomics 1998; 51: 160-1.

153 Gárdos G. The function of calcium in the potassium permeability of human erythrocytes. Biochim Biophys Acta 1958; 30: 653-4.

154 Ishii TM, Silvia C, Hirschberg B, Bond CT, Adelman JP, Maylie J, et al. A human intermediate conductance calcium-activated potassium channel. Proc Natl Acad Sci U S A 1997; 94: 11651-6.

155 Joiner WJ, Wang LY, Tang MD, Kaczmarek LK. hSK4, a member of a novel subfamily of calcium-activated potassium channels. Proc Natl Acad Sci U S A 1997; 94: 11013-8.

156 Fanger CM, Ghanshani S, Logsdon NJ, Rauer H, Kalman K, Zhou J, et al. Calmodulin mediates calcium-dependent activation of the in- termediate conductance $\mathrm{K}_{\mathrm{Ca}}$ channel, $I_{\mathrm{KCa} 1}$. J Biol Chem 1999; 274; 5746-54.

157 Khanna R, Chang MC, Joiner WJ, Kaczmarek LK, Schlichter LC. hSK4/hIK1, a calmodulin-binding kca channel in human t lymphocytes: roles in proliferation and volume regulation. J Biol Chem 1999; 274: 14838-49.

158 Joiner WJ, Khanna R, Schlichter LC, Kaczmarek LK. Calmodulin regulates assembly and trafficking of SK4/IK1 Ca ${ }^{2+}$-activated $\mathrm{K}^{+}$channels. J Biol Chem 2001; 276: 37980-5.

159 Pellegrino M, Pellegrini M. Modulation of $\mathrm{Ca}^{2+}$-activated $\mathrm{K}^{+}$channels of human erythrocytes by endogenous cAMP-dependent protein kinase. Pflügers Arch Eur J Physiol 1998; 436: 749-56.

160 Gerlach AC, Gangopadhyay NN, Devor DC. Kinase-dependent regulation of the intermediate conductance, calcium-dependent potassium channel, hIK1. J Biol Chem 2000; 275: 585-98.

161 Gerlach AC, Syme CA, Giltinan L, Adelman JP, Devor DC. ATP-dependent activation of the intermediate conductance, $\mathrm{Ca}^{2+}$-activated $\mathrm{K}^{+}$ channel, hlK1, is conferred by a C-terminal domain. J Biol Chem 2001; 276: 10963-70.

162 Grundemann J, Clark BA. Calcium-activated potassium channels at nodes of ranvier secure axonal spike propagation. Cell Rep 2015; 12: 1715-22.

163 von Hahn T, Thiele I, Zingaro L, Hamm K, Garcia-Alzamora M, Köttgen $\mathrm{M}$, et al. Characterisation of the rat SK4/IK1 $\mathrm{K}^{+}$channel. Cell Physiol Biochem 2001; 11: 219-30.

164 Wulff H, Kohler R. Endothelial small-conductance and intermediateconductance $\mathrm{K}_{\mathrm{Ca}}$ channels: an update on their pharmacology and usefulness as cardiovascular targets. J Cardiovasc Pharmacol 2013; 61: 102-12.

165 Beqqali A, van Eldik W, Mummery C, Passier R. Human stem cells as a model for cardiac differentiation and disease. Cell Mol Life Sci 2009; 66: 800-13.

166 Hescheler J, Fleischmann BK, Lentini S, Maltsev VA, Rohwedel J, Wobus AM, et al. Embryonic stem cells: a model to study structural and functional properties in cardiomyogenesis. Cardiovasc Res 1997; 36: 149-62.

167 Liang H, Halbach M, Hannes T, Fleischmann BK, Tang M, Schunkert H, et al. Electrophysiological basis of the first heart beats. Cell Physiol Biochem 2010; 25: 561-70.

168 Zhang J, Wilson GF, Soerens AG, Koonce CH, Yu J, Palecek SP, et al. Functional cardiomyocytes derived from human induced pluripotent stem cells. Circ Res 2009; 104: e30-e41.

169 Wang K, Xue T, Tsang SY, Van Huizen R, Wong CW, Lai KW, et al. Electrophysiological properties of pluripotent human and mouse embryonic stem cells. Stem Cells 2005; 23: 1526-34.

170 Dolnikov K, Shilkrut M, Zeevi-Levin N, Gerecht-Nir S, Amit M, Danon $A$, et al. Functional properties of human embryonic stem cell-derived cardiomyocytes: intracellular $\mathrm{Ca}^{2+}$ handling and the role of sarcoplasmic reticulum in the contraction. Stem Cells 2006; 24: 236-45.

171 Satin J, Itzhaki I, Rapoport S, Schroder EA, Izu L, Arbel G, et al. Calcium handling in human embryonic stem cell-derived cardiomyocytes. Stem Cells 2008; 26: 1961-72.

172 Zhu WZ, Santana LF, Laflamme MA. Local control of excitation-contraction coupling in human embryonic stem cell-derived cardiomyocytes. PloS One 2009; 4: e5407.

173 Weisbrod D, Peretz A, Ziskind A, Menaker N, Oz S, Barad L, et al. $\mathrm{SK} 4 \mathrm{Ca}^{2+}$ activated $\mathrm{K}^{+}$channel is a critical player in cardiac pacemaker derived from human embryonic stem cells. Proc Natl Acad Sci U S A 2013; 110: E1685-1694.

174 BoSmith RE, Briggs I, Sturgess NC. Inhibitory actions of ZENECA ZD7288 on whole-cell hyperpolarization activated inward current $\left(I_{f}\right)$ 
in guinea-pig dissociated sinoatrial node cells. Br J Pharmacol 1993; 110: 343-9.

175 Sartiani L, Bettiol E, Stillitano F, Mugelli A, Cerbai E, Jaconi ME. Developmental changes in cardiomyocytes differentiated from human embryonic stem cells: a molecular and electrophysiological approach. Stem Cells 2007; 25: 1136-44.

176 Goethals M, Raes A, van Bogaert PP. Use-dependent block of the pacemaker current $l_{\mathrm{f}}$ in rabbit sinoatrial node cells by zatebradine (UL-FS 49). On the mode of action of sinus node inhibitors. Circulation 1993; 88: 2389-401.

177 Hobai IA, Khananshvili D, Levi AJ. The peptide "FRCRCFa", dialysed intracellularly, inhibits the $\mathrm{Na} / \mathrm{Ca}$ exchange in rabbit ventricular myocytes with high affinity. Pflugers Arch 1997; 433: 455-63.

178 Watano T, Kimura J, Morita T, Nakanishi H. A novel antagonist, No. 7943 , of the $\mathrm{Na}^{+} / \mathrm{Ca}^{2+}$ exchange current in guinea-pig cardiac ventricular cells. Br J Pharmacol 1996; 119: 555-63.

179 Sanders L, Rakovic S, Lowe M, Mattick PA, Terrar DA. Fundamental importance of $\mathrm{Na}^{+}-\mathrm{Ca}^{2+}$ exchange for the pacemaking mechanism in guinea-pig sino-atrial node. J Physiol 2006; 571: 639-49.

180 Chen F, De Diego C, Chang MG, McHarg JL, John S, Klitzner TS, et al. Atrioventricular conduction and arrhythmias at the initiation of beating in embryonic mouse hearts. Dev Dyn 2010; 239: 1941-9.

181 Suenari K, Cheng CC, Chen YC, Lin YK, Nakano Y, Kihara Y, et al. Effects of ivabradine on the pulmonary vein electrical activity and modulation of pacemaker currents and calcium homeostasis. J Car- diovasc Electrophysiol 2012; 23: 200-6.

182 Yaniv Y, Sirenko S, Ziman BD, Spurgeon HA, Maltsev VA, Lakatta EG. New evidence for coupled clock regulation of the normal automaticity of sinoatrial nodal pacemaker cells: bradycardic effects of ivabradine are linked to suppression of intracellular $\mathrm{Ca}^{2+}$ cycling. J Mol Cell Cardiol 2013; 62: 80-9.

183 Kleger A, Seufferlein T, Malan D, Tischendorf M, Storch A, Wolheim A, et al. Modulation of calcium-activated potassium channels induces cardiogenesis of pluripotent stem cells and enrichment of pacemaker-like cells. Circulation 2010; 122: 1823-36.

184 Kleger A, Liebau S. Calcium-activated potassium channels, cardiogenesis of pluripotent stem cells, and enrichment of pacemaker-like cells. Trends Cardiovasc Med 2011; 21: 74-83.

185 Liebau S, Tischendorf M, Ansorge D, Linta L, Stockmann M, Weidgang $C$, et al. An inducible expression system of the calciumactivated potassium channel 4 to study the differential impact on embryonic stem cells. Stem Cells Int 2011; 2011: 456815.

186 Müller M, Stockmann M, Malan D, Wolheim A, Tischendorf M, Linta $\mathrm{L}$, et al. $\mathrm{Ca}^{2+}$ activated $\mathrm{K}$ channels-new tools to induce cardiac commitment from pluripotent stem cells in mice and men. Stem Cell Rev 2012; 8: 720-40.

187 Horsthuis T, Buermans HP, Brons JF, Verkerk AO, Bakker ML, Wakker V, et al. Gene expression profiling of the forming atrioventricular node using a novel Tbx3-based node-specific transgenic reporter. Circ Res 2009; 105: 61-9. 